Historic, Archive Document

Do not assume content reflects current scientific knowledge, policies, or practices. 



\section{ORCHIDWOOD, INC.}

830 PELHAMDALE AVENUE NEW ROCHELLE, NEW YORK 


$$
2 \log l g(0)
$$




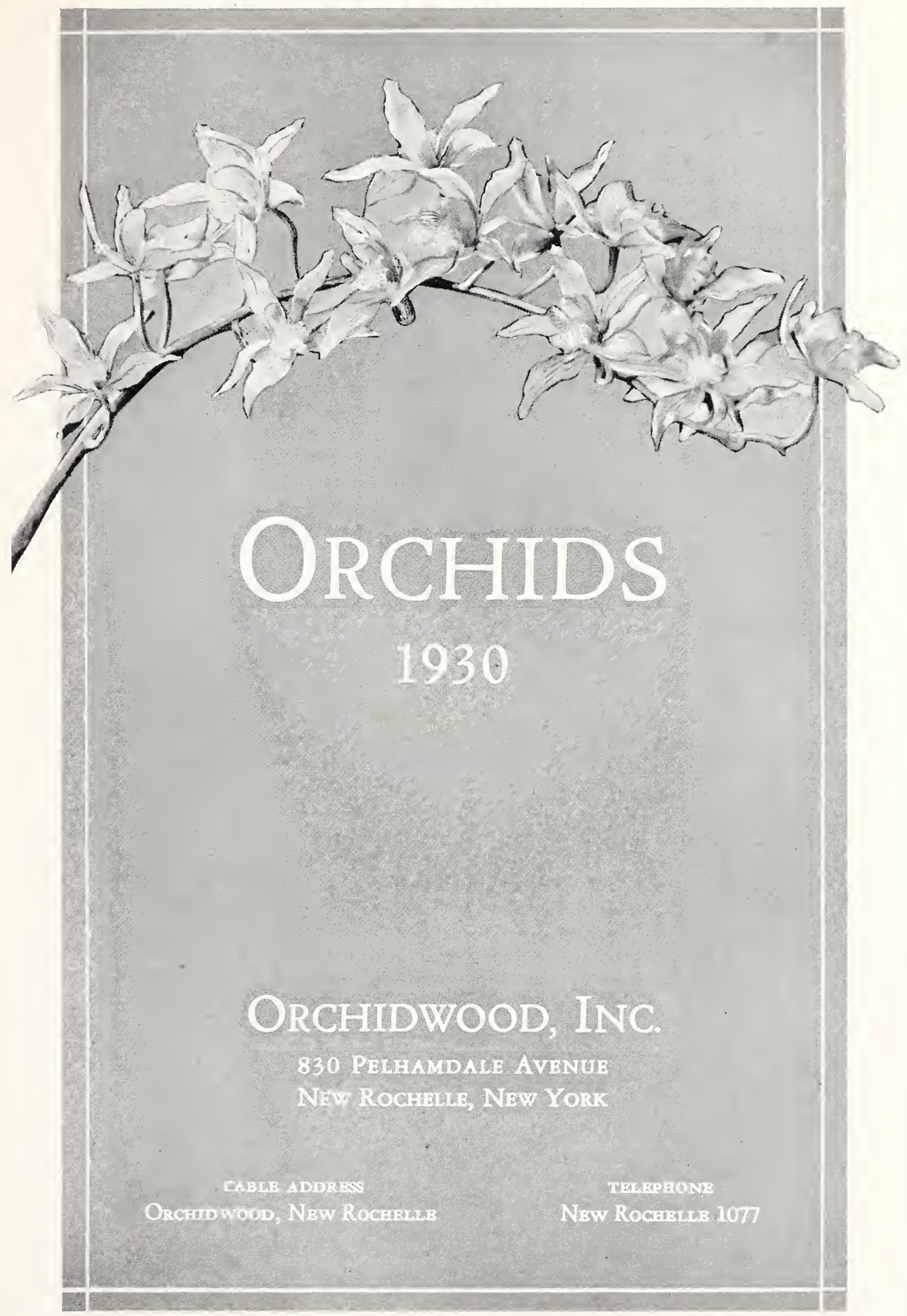




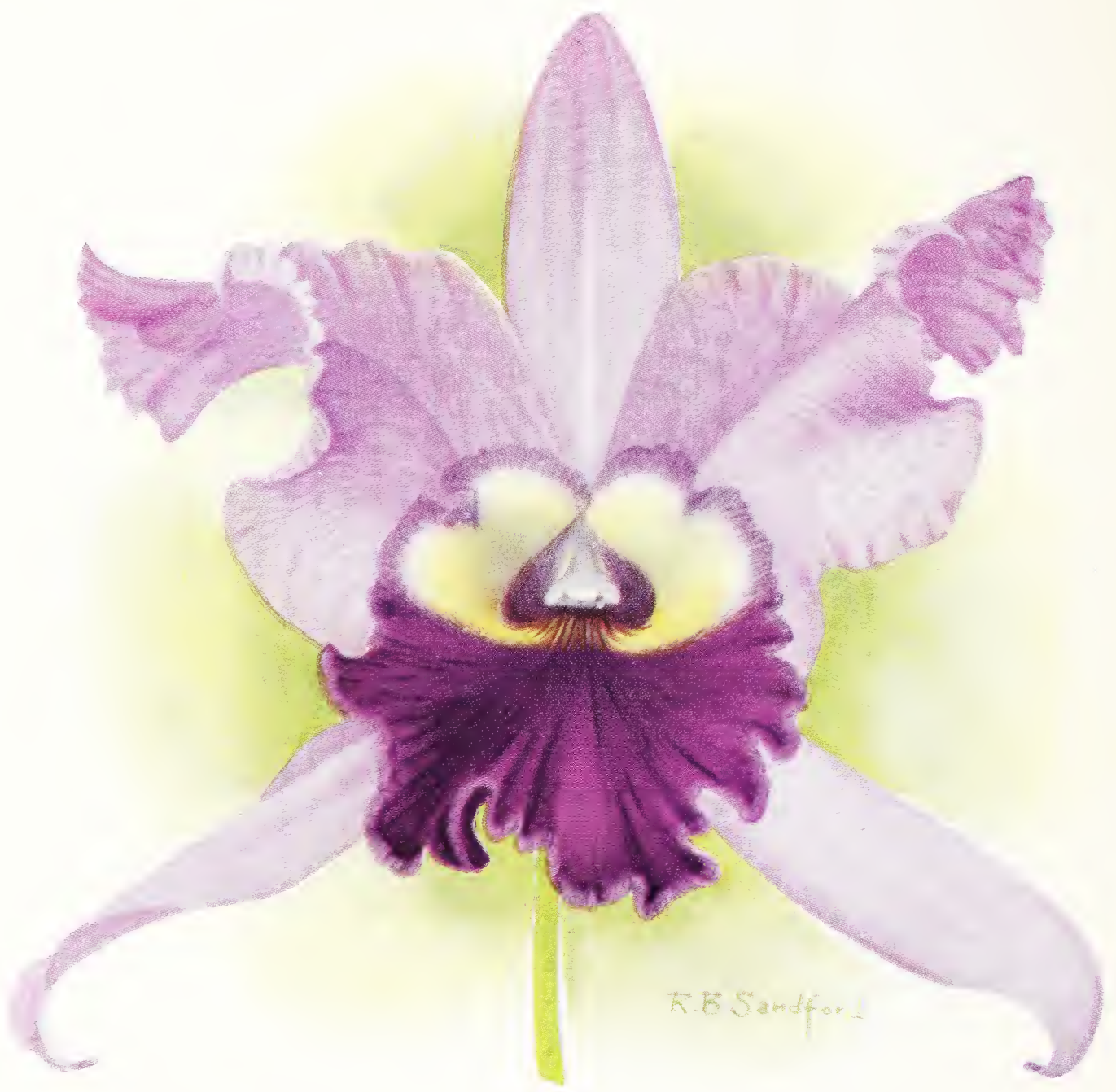

LAELIOCATTLEYA WELLESLEYI

Variety Edward H. Roehrs

(See page 25) 


\section{Foreword}

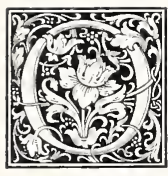

UR FIRST Catalogue of Orchids has been so well received that we feel encouraged to go ahead with this, our second Catalogue and Price List. In this work we have added many new and interesting varieties, some of which are exclusive to our own estab. lishment.

"Orchidwood" has grown considerably in the past year through the acquisition of the four large greenhouses formerly owned by David Clarke and Sons, the extension of our old houses from eighty-five feet to one hundred fifty feet, and the construction of a new separate building for our laboratory. We have secured and will continue to acquire the finest stock available, so that the Orchid-buying public may be assured of the high-grade quality of our seedlings.

We CORDIALLY invite inspection of our establishment, which is one of the most uptodate in America; and we are always glad to show anyone interested in Orchids just what we are doing to advance the culture of these "Aristocrats." We welcome at all times any inquiries regarding the growing of Orchids, and will endeavor to answer promptly all correspondence on this subject.

To тнe average layman, Orchids have been more or less of a mystery whose cultural requirements were such as to demand the whole-time attention of a skilled expert, and which required a fortune to purchase even a modest collection. Given moderate attention, the investment of a small sum in good varieties of Orchids will show greater dividends than an equal sum expended in any other kind of plants. Any structure that deserves the name of greenhouse will be suitable for the growing of some species in this large family; yet to derive maximum results from the plants selected, the house should be capable of supplying, approximately, the few needs of its inmates in the matter of light, heat and moisture. These few general hints, which we hope will be of assistance to the beginner, may be supplemented by information given on each genus to be found in the books listed here.

Light. In this Northern latitude, we find that the majority of Orchids need all the light possible in the dull days of Winter. As Spring advances, a light coating of paint mixed with gasolene is necessary to diminish the burning effect of the sun's rays on the glass; and in Summer, an additional coat or two will help to diffuse the strong glare. Weather conditions wiil usually remove most of this shading by November when the remainder may be washed off. On small houses roller blinds may be used to advantage and, if placed six or so inches above the glass, will allow a free circulation of air over the roof. 
Temperature. Remember that too much fire heat is dangerous-err on the safe side. Cattleyas and Laeliocattleyas succeed in a temperature of $60-63^{\circ}$ at night, rising by sun heat to $75-80^{\circ}$, during their growing season. Brassocattleyas can benefit by slightly more heat, if such can be given without affecting other plants in the house. Vandas like a warm corner where shading is not very heavy. The majority of miscellaneous species can be grown in much cooler temperature, say $55-60^{\circ}$ at night, rising appreciably by day.

Ventilation. Fresh air should be admitted at all times when the weather permits, and the use of bottom ventilators, allowing the air to pass over the warm pipes, is to be commended. A free circulation is encouraged by opening, very slightly, the top vents, being careful not to create a draught.

Potting. Generally speaking, potting is done when the plants resume active growth, which is evident by the pushing of new roots. The medium used - Osmunda fiber-is chopped into pieces suited to the size of the plant; that is, for big plants the fiber can be left in good sized chunks, while it can be pulled into shreds for little seedlings. In potting young plants and those requiring an added rooting stimulus, the addition of Sphagnum is beneficial. When potted, the plants should not have any disturbance of roots until it is necessary to again repot, say in two years. Newly potted plants should be kept on the dry side until established in the fresh compost, only an occasional spraying overhead being necessary.

Moisture. During the growing season, damping the walks and benches may be done four or five times a day, whilst in Winter, twice may be enough. When in full root action, all Orchids can be heavily watered, indeed, a full supply is necessary to secure plump bulbs, the Orchid's reservoir of nourishment. Whilst resting, less water is given, and atmospheric conditions are kept less humid.

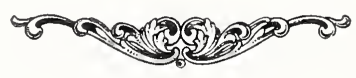

\section{Books on Orchids}

American Orchid Culture. By Prof. E. A. White. The only book written in America for both amateur and professional.

Cloth, $\$ 4.50$

The Book of the Orchid. By $W$. H. White. Contains many hints on growing, potting, ventilation, etc.

Cloth, $\$ 1.50$

The Orchid Growers' Manual. By B. S. Williams. Descriptions of about 2500 species and varieties.

Cloth, $\$ 10.00$

Sander's Orchid Guide. By H. F. C. Sander. Describes all the best known genera and species.

Cloth, $\$ 8.00$

\section{ORCHIDWOOD, INC.}

formerly Thomas C. Kirkwood, Inc. 


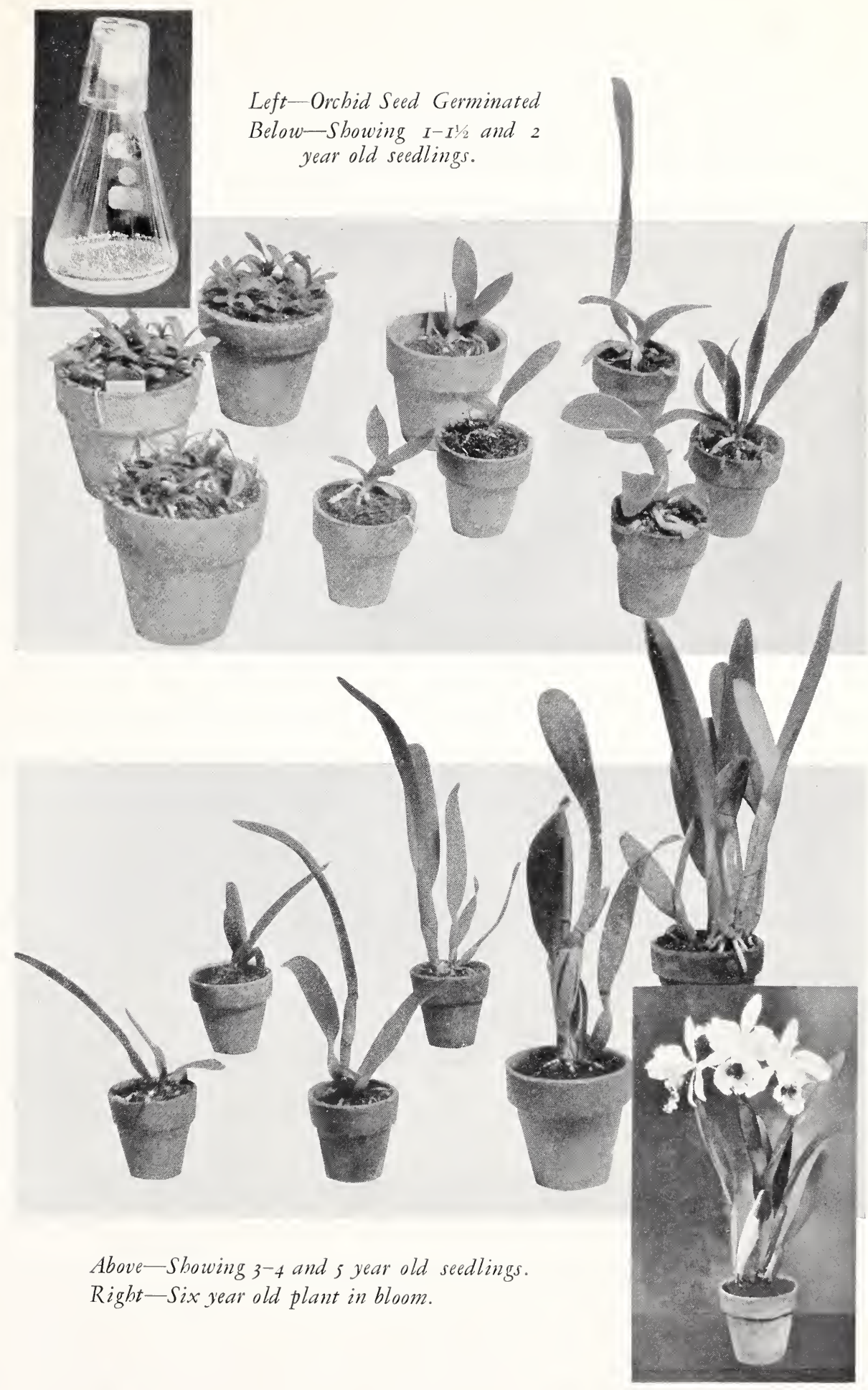




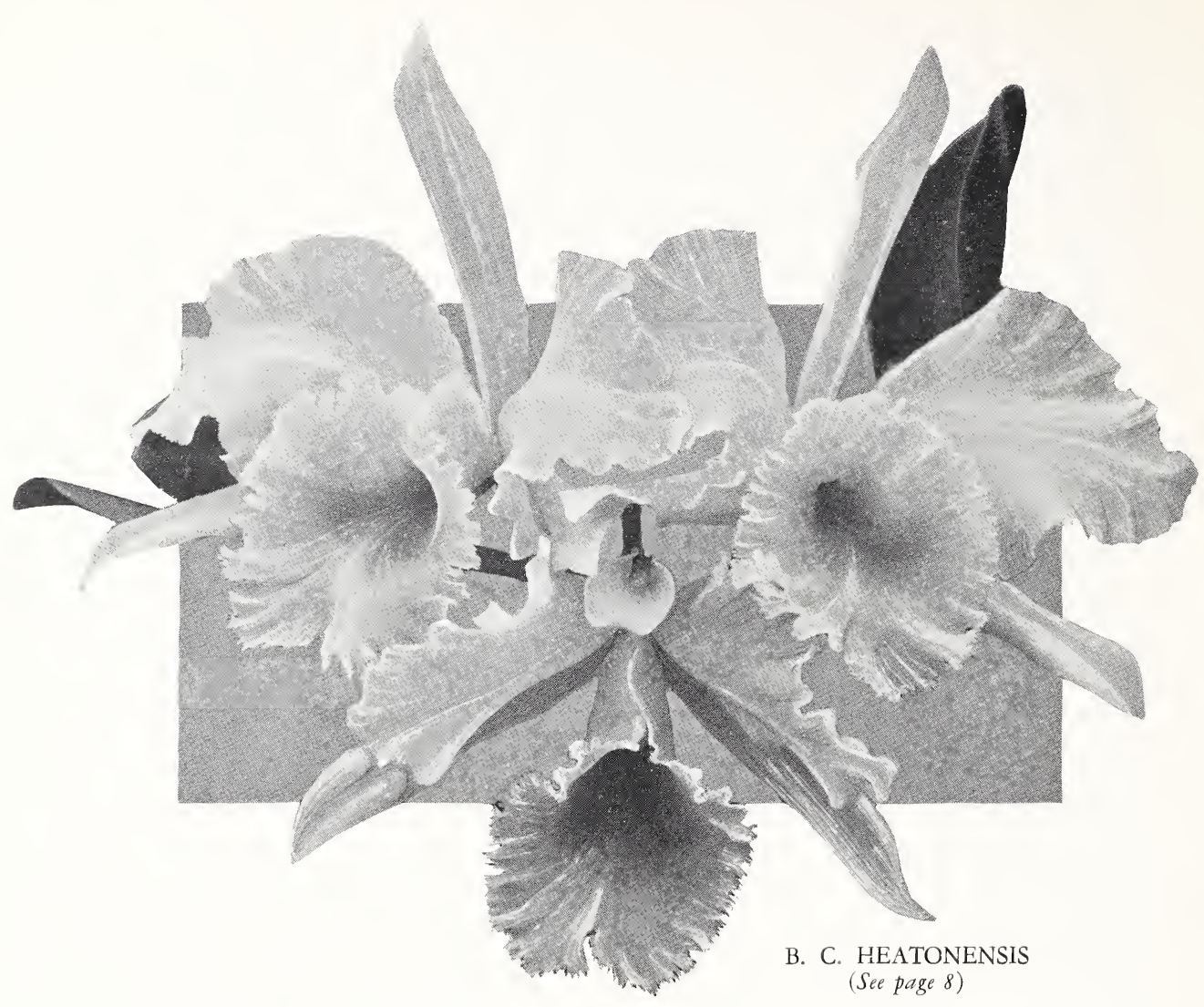

\section{Brassocattleyas}

T HESE gorgeous hybrids are becoming more popular each year, and in every collection they are pointed out with pride as being the "elite" members of the group. The wonderful fringe on the lip, inherited from Brassavola Digbyana, coupled with the fine colors of the Cattleya make a very impressive flower. Our stock of these bigeneric hybrids is very complete, and we hope to still add to it from time to time as our seedlings reach maturity. The plants mentioned below are established representatives having four or five bulbs with one lead.

B. C. America (B. C. Mme. C. Maron X C. Cooksoni). One of the same batch of seedlings has won a Gold Medal for excellence at New York Show. Only three plants in stock

B. C. Andre Maron (B. C. Mrs. J. Leemann X C. Schroederce). Soft pastel shades, with pleasing fragrance . . . . . . . . 30.00

B. C. Dr. G. MacDonald (B. C. Ilene $\times$ C. Peetersi). One of the best shaped varieties of Brassocattleya . . . . . . . . . 35.00

B. C. Imperatrice de Russie (B. Digbyana $\times$ C. Mendeli). Light colored flowers of good substance . . . . . . . . . 25.00

B. C. F. E. Dixon (B. C. Digbyana-Schroederce $\times$ C. Dowiana). The well marked lip is a prominent feature . . . . . . . . 35.00

B. C. Fusilier (B. C. Mrs. J. Leemann X C. Hardyana) . . . . . 35.00 


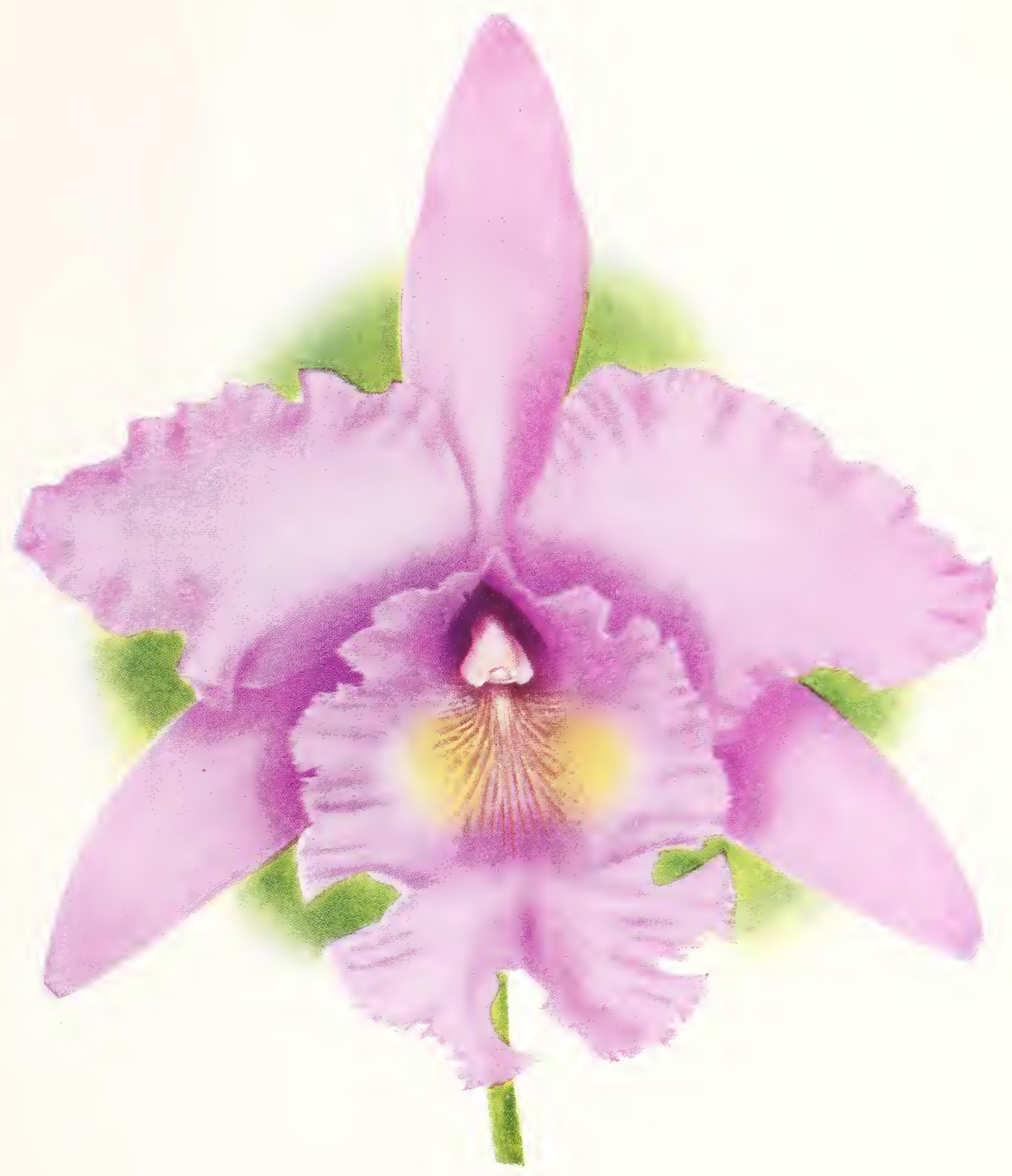

BRASSOCATTLEYA PENELOPE. (See page 8) 
B. C. heatonensis (B. Digbyana $\times$ C. Hardyana). A very useful, free flowering hybrid of good shape. (See illustration, page 6.) $\$ 20.00$

B. C. Ilene (B. C. Mme. C. Maron X C. Dowiana) . . . . . . . 30.00 Special Variety . . . . . . . . . . . . . . . . . 50.00

B. C. Joyce Jewell (B. Digbyana $\times$ C. Percivaliana). A lovely rose pink with yellow throat . . . . . . . . . . 35.00

B. C. Mme. C. Maron (B. Digbyana XC.gigas). One of the most popular of all Brassovola hybrids . . . . . . . . . 20.00

B. C. Madeline (B. C. Mme. C. Maron X C. Triane). A steady Winterflowering variety . . . . . . . . . . . . 30.00

B. C. Marguerite Fournier (B. Digbyana X C. labiata). . . . 20.00

B. C. Mrs. J. Leemann (B. Digbyana $\times$ C. Dowiana). The varying shades of creamy yellow are very pleasing. . . . . . . . . 20.00 Good Variety . . . . . . . . . . . . . . . 30.00

B. C. Nestor (B. C. Mme. C. Maron X C. labiata). One of the largest of bigeneric hybrids......... . . . . . . . 20.00 Larger Plants . . . . . . . . . . . . . . 35.00

B. C. Penelope (B. C. Mme. C. Maron X C. Fabia). The influence of C. Fabia is seen in the rich coloring. . . . . . 30.00 Fine Variety. (See Color Plate, page 7.) . . . . 50.00

B. C. Possehli (B. C. Princess Patricia X C. Hardyana) . . . . . 35.00

B. C. Ruby (B. C. Mrs. J. Leemann X C. labiata) (var. Peetersi) _. 35.00

B. C. Sioux (B. C. Mrs. J. Leemann X C. Zephyr) . . . . . . 20.00

B. C. Springtide (B. C. Mme. C. Maron X C. Mossice). . . . . 25.00

B. C. Thorntoni (B. Digbyana $\times$ C. Gaskelliana). A very useful variety of easy culture . . . . . . . . . . . . . . . . 20.00

B. C. Veitchi (B. Digbyana $\times$ C. Mossive). Has well shaped flowers of good color . . . . . . . . . . . . . . 20.00

B. C. Willing (B. C. Pocahontas X C. Gaskelliana) . . . 20.00

\section{Brassolaelias}

$\prod$ HE free flowering qualities of Laelia, coupled with the large fringed lip of the Brassovola, give us an extremely satisfactory combination. Their culture is easy; and if a slightly warmer corner can be found at the end of the greenhouse they will repay all the attention bestowed. Plants offered have four or five bulbs with one lead.

B. L. Helen (B. Digbyana $\times$ L. tenebrosa). The variations in color range from creamy white to deep yellow. Exceptionally free flowering, often twice a year.

Fine Yellow Variety

B. L. Louis-BeL (B. Digbyana $\times$ L. Boothiana) . . . . . . . 15.00

B. L. VeItchi (B. Digbyana $\times$ L. purpurata) . . . . . . . . . 15.00 


\section{Brassolaeliocattleyas}

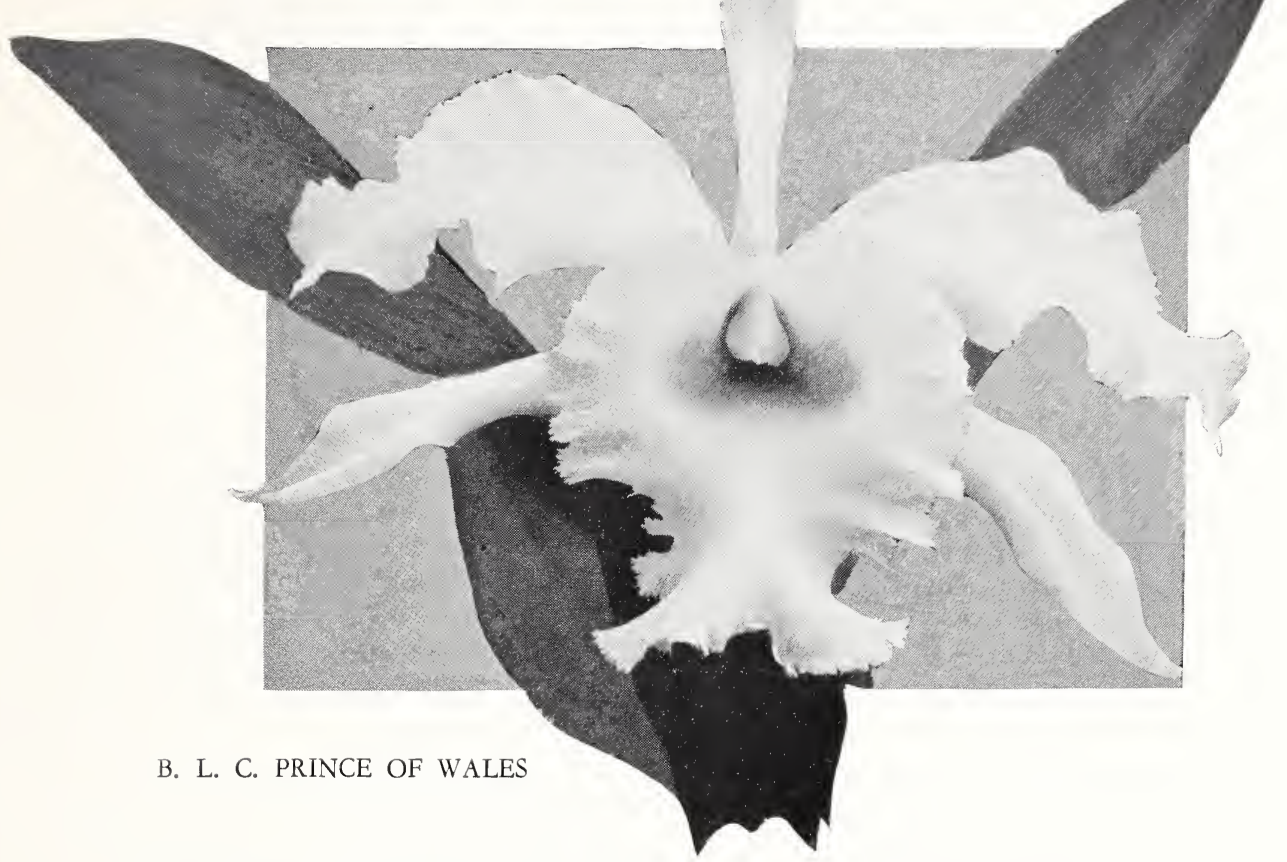

THE influence of Laelia in the makeup of these trigeneric hybrids lends a freedom of growth and a brightness of coloring. Although the fringed lip is still the most prominent feature of the beautiful blooms, ther retain the depth of color found in Laeliocattleyas. Plants mentioned have four or five bulbs with one lead.

B. L. C. Afterglow (B. C. Thorntoni $\times$ L. C. Rover). This new hybrid promises to supersede many of the old varieties . . . . $\$ 30.00$

B. L. C. Britain's King (B. L. Veitchi X C. Gertrude) . . . . . . . 15.00

B. L. C. Fenimore (B. L. C. Triune X L. C. Hyeana) . . . . . . 20.00

B. L. C. Hymen (B. C. Veitchi X L. C. Hyeana) . . . . . . . . 20.00

B. L. C. Kenneth (B. Digbyana $\times$ L. C. Wellsiana). One of the heavilyfringed-lip type . . . . . . . . . . . . 20.00

B. L. C. Lady Diana (B. L. Veitchi X C. Dowiana). A well-balanced flower of good shape and color . . . . . . . . . 20.00

B. L. C. Metacomet (B. L. Helen X L. C. Berthe Fournier) . . . . 20.00

B. L. C. Prince of Wales (L.C. Dominiana $\times$ B. C. Veitchi). Faintly suffused with pink and purple on petals and sepals. (See illustration above.) . . . . . . . . . . . . . 30.00

B. L. C. Rowena (B. Digbyana X L. C. Doris) . . . . . . . . 25.00

B. L. C. The Baroness (B.C Mrs. J. Leemann X L. C. Ophir). One plant only . . . . . . . . . . . . . 50.00 


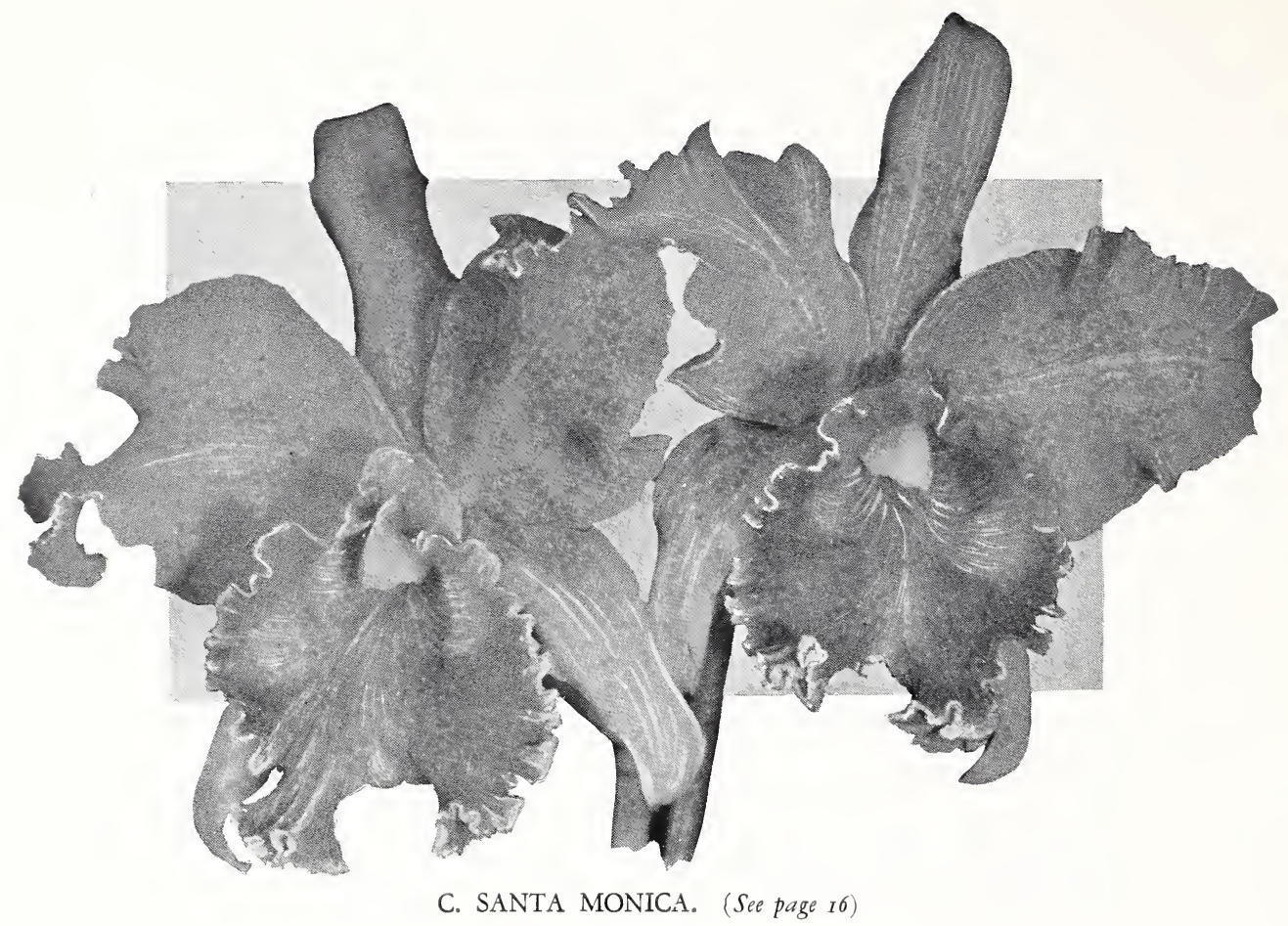

\section{Cattleya Hybrids}

$\mathbb{T}$ HESE form the bulk of almost every collection in America, being in many cases the "bread and butter" to the commercial grower. The almost endless combination of Cattleya crossed with Cattleya has raised the standard far above the average conception of just "a Cattleya." Being all home-raised, their constitutions have adapted themselves to American climatic conditions, and the amateur can look for great success in the growing of the following varieties which have, on the average, four or five bulbs with one lead.

C. Abekeniae (Dowiana $\times$ Lord Rothschild). The influence of $C$. Dowiana twice used is evident in the rich coloring of the lip

C. Adela (Percivaliana $\times$ Trianae). A true Winter variety of deep color . 20.00

C. Adula $($ Bicolor $\times$ Hardyana $)$. . . . . . . . . . 15.00 Special Variety. Deep bronze . . . . . . . . . . . . 30.00

C. Amabilis (labiata $\times$ gigas). Free growing type, with strong flower stems . . . . . . . . . . . . . . . 20.00 Good Variety . . . . . . . . . . . . . . . 30.00

C. armainvillierensis (Mendeli $\times$ gigas). Blooming in early Fall, this variety is much in demand . . . . . . . . . . 25.00 ALBA . . . . . . . . . . . . . . . 35.00

C. Ardens (Hardyana $\times$ Dupreana) . . . . . . . . . . . 20.00

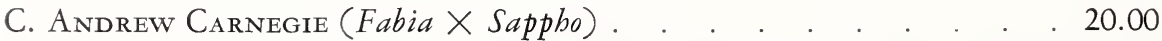




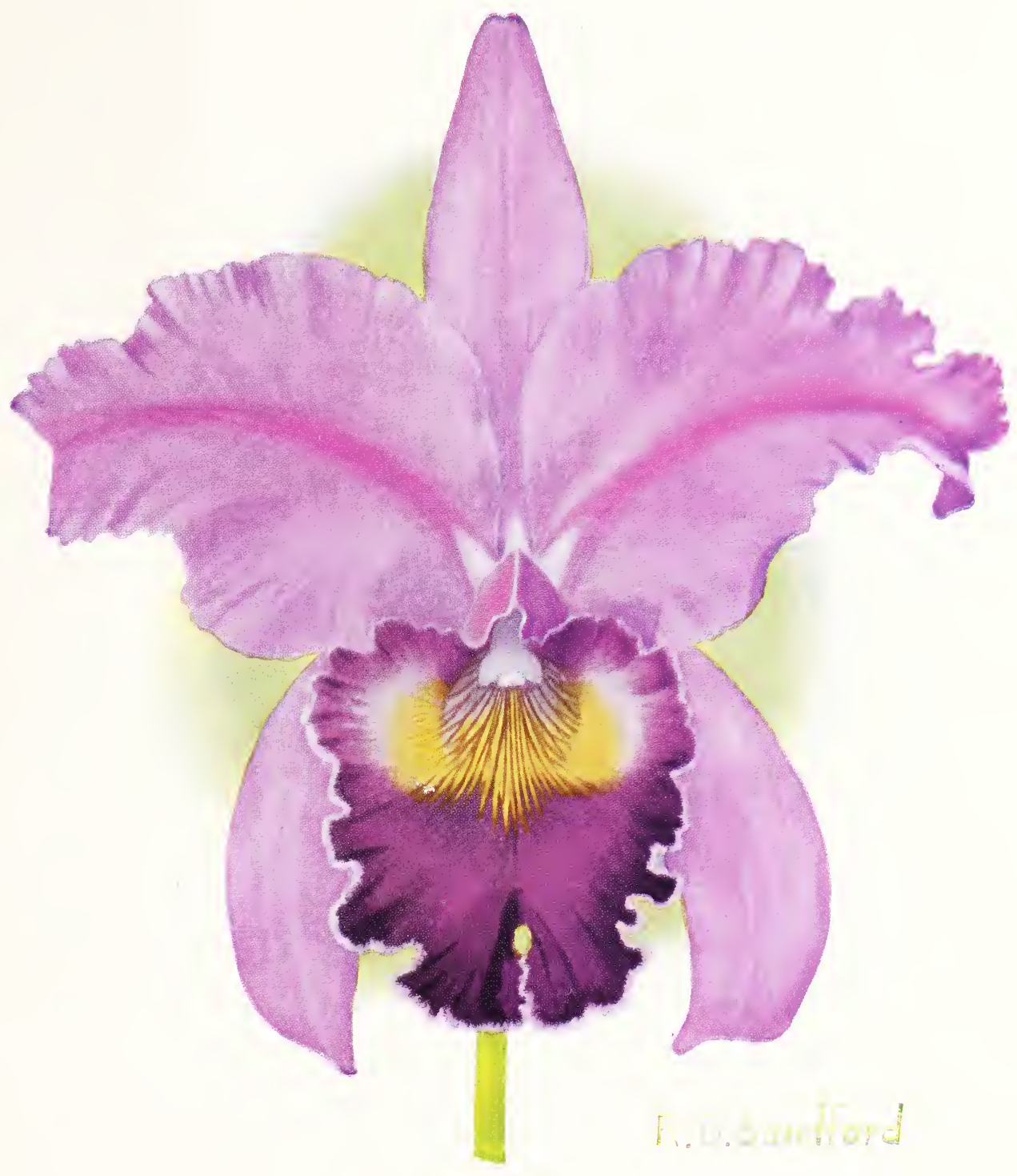

CATTLEYA GAY GORDON. (See page I2) 
C. Armstrongie (Hardyana $\times$ Loddigesi)

.$\$ 15.00$

C. Ashtoni (Harrisoniana $\times$ gigas). Flowers slightly smaller, but more in number than the average

C. Atalanta (Leopoldi $\times$ gigas)

C. Ballantineana (Trianae $\times$ gigas). Large, bold flower of good color and size .

Extra Variety

40.00

C. Bella Simpson (suavior $\times$ Triane).

C. Berti (Harrisoniana $\times$ labiata) .

C. Blacki (Gaskelliana $\times$ Mendeli)

C. BoAdicea (Gaskelliana $\times$ Hardyana) 20.00

C. Сомet (Dowiana $\times$ Warneri). One of the best primary hybrids 25.00 Fine Variety. Magnificent deep color throughout .

C. Cooksoni (Hardyana $\times$ Triane). Blooms are much appreciated in late Fall .

C. Cybele (Gaskelliana $\times$ Lueddemanniana). Round flowers with fine petals. aLba. Pure white; June to July .

C. Dionysius (Fabia $\times$ gigas). Its fine form attracts attention everywhere it is seen ALBA

C. Donald Mackenzie (Hardyana $\times$ Miss Williams) 20.00

C. Dubiosa (Harrisoniana $\times$ Triance) . 15.00

C. Eleanor Gray (Dowiana $\times$ Marriottiana) 20.00

C. Eleanore (Hardyana $\times$ gigas) . . . . . . . . . . . . . 20.00 ALBA. Greatly resembles Laeliocattleya Schroederæ . . . 35.00

C. Empress Frederick (Dowiana $\times$ Mossia). Well-balanced flower of good size . . . . . . . . . . . . . . . . 35.00

C. Enid (Mossice $\times$ gigas). One of the largest of hybrid Cattleyas, whose flowers always command good prices Good Variety

C. FABIA (Dowiana $\times$ labiata). We have some exceptionally fine specimens of this popular variety .

C. Flora MacDonald (Fabia $\times$ Boadicea)

C. Freya (Dowiana $\times$ Mantini)

C. GAY Gordon (Hardyana X Van Houtte) . 
C. General Pulteney (Octave Doin X Trianc). A great improvement over the species when Winter hybrids are in demand . . . \$20.00

C. Gildeni (Hardyana X Maggie Raphael). A very consistent Fall bloomer 25.00

C. Gladys (Atalanta $\times$ Dowiana). Well-shaped flowers in lovely pastel shades . . . . . . . . . . . . 20.00 Good Variety . . . . . . . . . . . . . . . 35.00

C. Gudrun (labiata $\times$ Mendeli $)$. . . . . . . . . . . 25.00

C. Hardyana (Dowiana $\times$ gigas). Our stock of this variety is probably the finest in the country . . . . . . . . . . 15.00 Good Variety . . . . . . . . . . . . . . . 25.00 ALBA . . . . . . . . . . . . . . 30.00

C. HAROLD (Gaskelliana $\times$ gigas). An extremely prolific bloomer; some of our plants have four and five leads, and give ten or more flowers . . . . . . . . . . . . . 20.00 Special Variety (See Color Plate, page 15) . . . . . . . 30.00

C. Hentschelli (Dupreana $\times$ gigas). Having twice $C$. gigas in its makeup, its flowers are of good size . . . . . . . . . . . 20.00

C. H. S. Leon (Schroedera $\times$ gigas). The soft shades of $C$. Schroedera are perpetuated in this fine hybrid. Fall variety . . . . . 20.00

C. intertexta (Mossice $\times$ Warneri) . . . . . . . . . . . 18.00

AlbA . . . . . . . . . . . . . 3500

C. Iris $($ bicolor $\times$ Dowiana $)$. . . . . . . . . . . . . . . . 15.00

C. John Knox (Dupreana $\times$ Mendeli) . . . . . . . . . . . 20.00

C. Jucunda $($ labiata $\times$ Schroederce $)$. . . . . . . . . . 15.00

C. Julienne $($ Mendeli $\times$ Skinneri $)$. . . . . . . . . . . . 15.00

C. Katadin (Empress Frederick $\times$ Lueddemanniana). Seedlings of this American hybrid have shown a wonderful depth of color . . 25.00 Good Variety . . . . . . . . . . . . . . . 35.00

C. Kensico $($ Enid $\times$ Zephyr $)$. . . . . . . . . . . . . 20.00

C. Kienastiana (Dowiana $\times$ Lueddemanniana). Well-formed flowers of good substance . . . . . . . . . . . . 20.00

C. Lady Evelyn (Atalanta $\times$ Hardyana) . . . . . . . . . . 15.00

C. Leda (Dowiana $\times$ Percivaliana). Our collection embraces some of the finest forms of this variety . . . . . . . . . . 30.00 Fine Variety . . . . . . . . . . . . . . 50.00

C. Lediata $($ labiata $\times$ Leda $)$. . . . . . . . . . . . . 20.00

C. Lieutenant Coppens (Dowiana $\times$ Undine). Of good color and fine shape . . . . . . . . . . . . . 20.00

C. Lord Derby (labiata $\times$ Percivaliana). The golden throat is transmitted to this well-formed hybrid . . . . . . . . 15.00

C. Lord Rothschild (Dowiana $\times$ Gaskelliana). An old favorite which still holds a high position 
C. Luegex $($ Enıd $\times$ Dowiana). Combines the fine shape of one parent with the coloring of the other. In every way a desirable variety. $\$ 25.00$

C. Magdalena Lowe (Dowiana $\times$ Prince Edward) . 18.00

C. Maggie Raphael (Dowiana $\times$ Triane). With its alba forms, this is one of the best commercial varieties Good Variety

C. Malcolm Canmore (armainvillierensis $\times$ Lueddemanniana). 20.00

C. Mantini (Bowringiana $\times$ Dowiana) Specimen Plant

C. Mrss Kemp (Bowringiana $\times$ Fabia). Has spikes of deep coiored flowers. 15.00

C. Miss M. Armstrong (Dowiana X Helen Langley). 18.00

C. Miss Williâms (Gaskelliana $\times$ Harrisoniana). 15.00

C. Molra (Fabia $\times$ Mantini) 18.00

C. Mount Royal (Enid $\times$ Maggie Raphael). 20.00 Fine Variety

C. Mrs. Elizabeth Peterson (Empress Frederick $\times$ Zephyr). Has lovely gold veining in the throat, with fine form

C. Mrs. Edward Roehrs (A. Dimmock $\times$ Triana)

C. Mrs. Myra Peeters (Gaskelliana alba $\times$ Warneri alba). A June variety; pure white flowers

C. Mrs. Pitt (Dowiana $\times$ Harrisoniana)

C. Mrs. Stewart Pool (Fabia $\times$ Moira) .

C. Octave Doin (Dowiana $\times$ Mendeli)

C. Peetersi (Hardyana $\times$ labiata). Among the best of the Fall blooming varieties.

C. Percimax (Maxima $\times$ Percivaliana). In coloring, this hybrid leans towards C. Maxima, with blooming period favoring the other parent

C. Pittiana (Dowiana $\times$ granulosa). Fair-sized flowers of good shape $\quad 15.00$

C. Portia (labiata $\times$ Bowringiana). Flowers are intermediate in size between those of its parents Specimen Plant

C. President Wilson (Fabia $\times$ labiata) .

C. Pretoria (Dowiana $\times$ Peetersi). The fine form of $C$. Peetersi plus the added color of $C$. Dowiana produces an excellent flower. Good Variety (See illustration, page 16.) .

C. Prince John (Dowiana $\times$ Hardyana). The influence of twice used C. Dowiana has given splendid coloring 


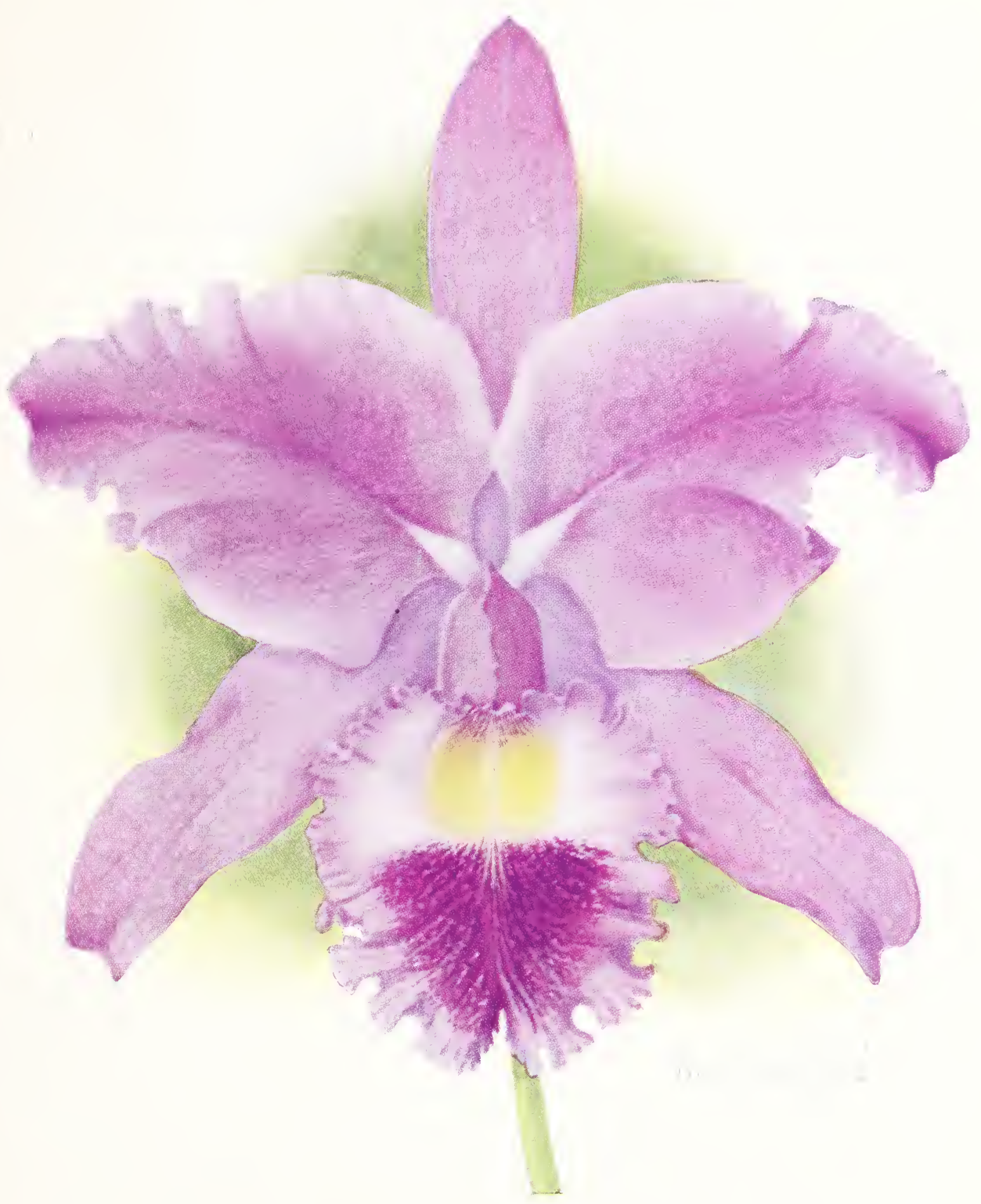

CATTLEYA HAROLD。 (See page 13) 


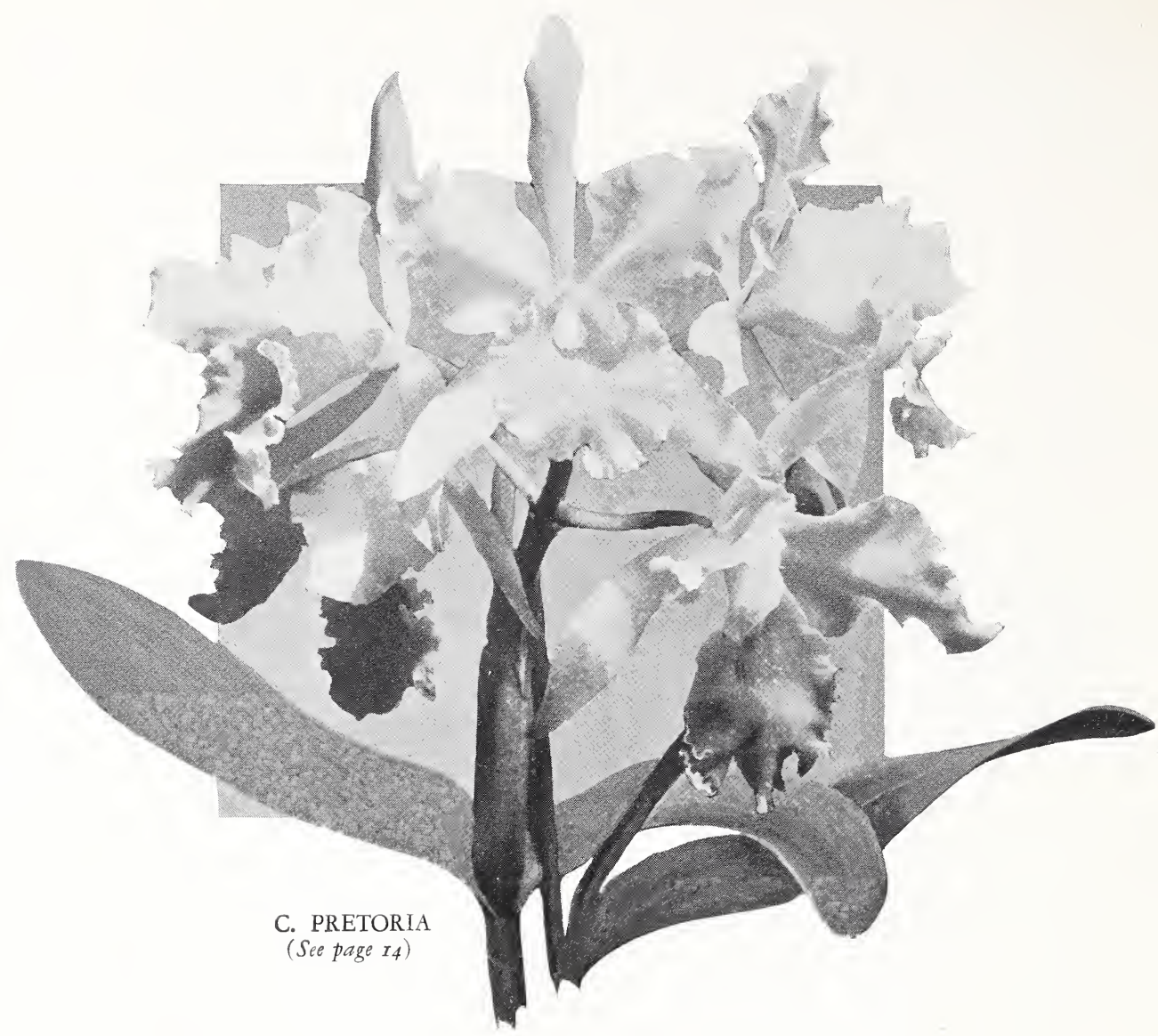

C. Quibo (Dowiana $\times$ Miss Williams). Some of these have a lovely mauve sheen on the petals and sepals . . . . . . . . . . . \$15.00 Good Variety . . . . . . . . . . . . . . . . . 25.00

C. Rhoda (Hardyana X Iris) . . . . . . . . . . . 18.00

Good Variety. Full lip . . . . . . . . . . . . 30.00

C. Robert Bruce (Dowiana $\times$ suavior $)$. . . . . . . . . . 15.00

C. Roemrsiana (Hardyana $\times$ Mendeli). Large flowers on a fine, long

stem . . . . . . . . . . . . 30.00

C. Santa Monica (Mendeli $\times$ Lord Rothschild). Good shape and color.

Fall variety. (See illustration, page 10.). . . . . . . 20.00

C. Shenandia (Lueddemanniana $\times$ Zephyr). Of recent introduction; a fine addition to our list . . . . . . . . . . . . 25.00

C. Shinjıк (maxima $\times$ Triana $)$. . . . . . . . . . . . . . 10.00

C. Sir Walter Scott $($ Harold $\times$ gigas $)$. . . . . . . . . . 18.00

C. suavior (intermedia $\times$ Mendeli). . . . . . . . . . . . 15.00

Trilobed Splasbed . . . . . . . . . . . . . 100.00 


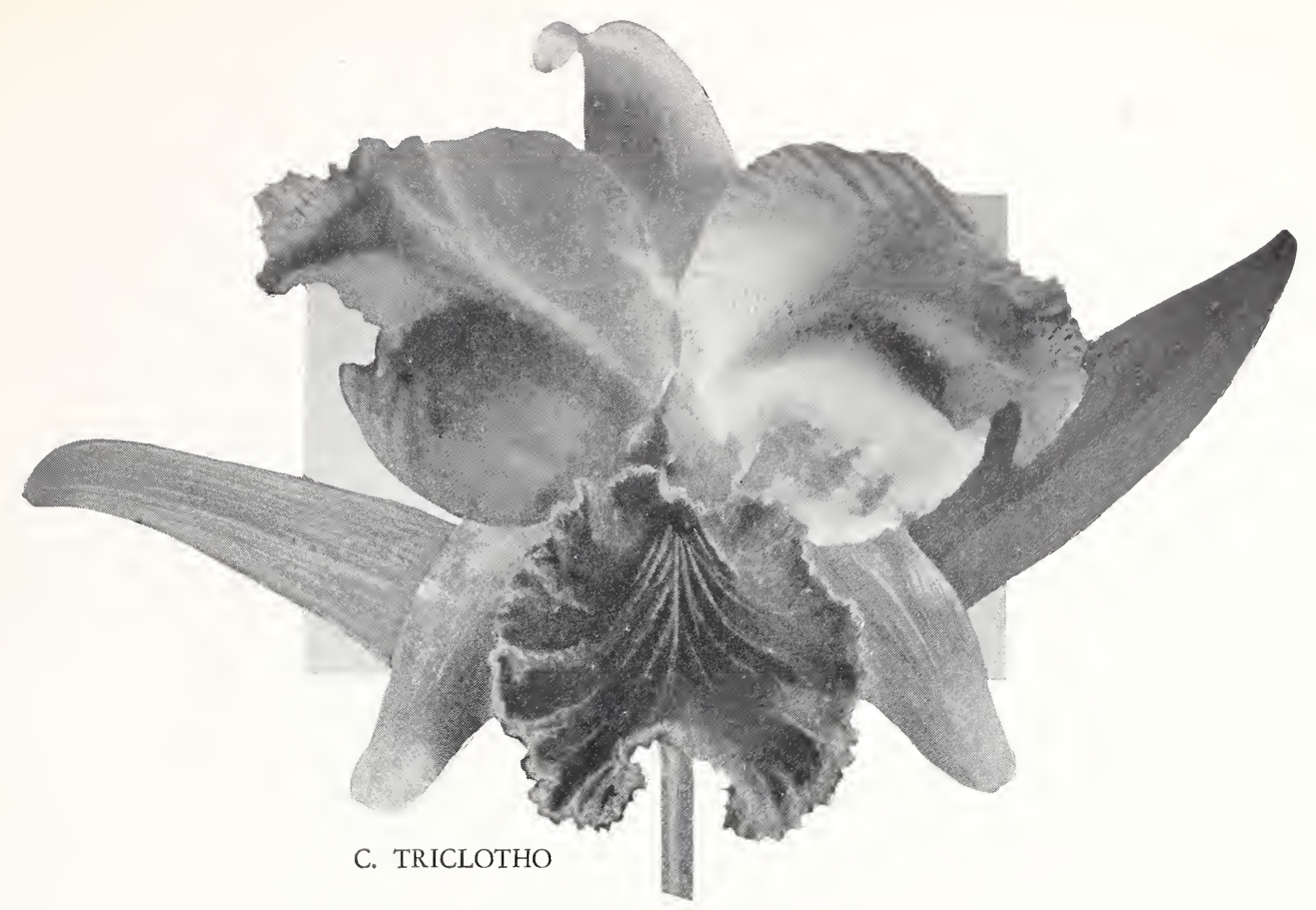

C. Sylvia (Dowiana $\times$ Fabia). An improvement over C. Fabia in richness of color, but of less robust constitution.

ALBA . . . . . . . . . . . . 35.00

C. Thomas C. Kirkwood (gigas $\times$ Princess Royal) . . . . . . . 25.00

C. Tityus (Enid $\times$ Octave Doin) . . . . . . . . . . 20.00

Good Variety . . . . . . . . . . . . . . . 30.00

C. Triclotho $($ Clotbo $\times$ Triane $)$. . . . . . . . . . . . 25.00

Fine Variety (See illustration above.) . . . . . . . . 50.00

C. Trimos (Triance $\times$ Mossice $)$. . . . . . . . . . . . 20.00

C. triumphans (Dowiana $\times$ Rex). Yellow petals and sepals . . . 35.00

C. VAN Houtte (Lord Rothschild $\times$ gigas). Splendid commercial variety . 20.00

Good Variety . . . . . . . . . . . . . 35.00

C. Venus (Dowiana $\times$ Iris) . . . . . . . . . . . . . . 15.00

Full lip, bronze petals and sepals . . . . . . . . . 25.00

Full lip, yellow petals and sepals . . . . . . . . . . 35.00

C. veriflora $($ labiata $\times$ Triane $)$. . . . . . . . . . . . 20.00

C. vestalis (Dowiana $\times$ maxima). Shows very plainly the influence of

C. maxima in coloring. . . . . . . . . . . . 15.00

C. Wendlandiana $($ Bowringiana $\times$ gigas $)$. . . . . . . . . 15.00

C. William Wallace $($ Dowiana $\times$ Hassilli). . . . . . . . . 25.00

C. Zephyr (Dowiana $\times$ Schroedera). Lovely pale flowers with delicate

fragrance. . . . . . . . . . 15.00

Good Variety . . . . . . . . . . . . . . . 30.00

New Rocbelle, N.Y. 


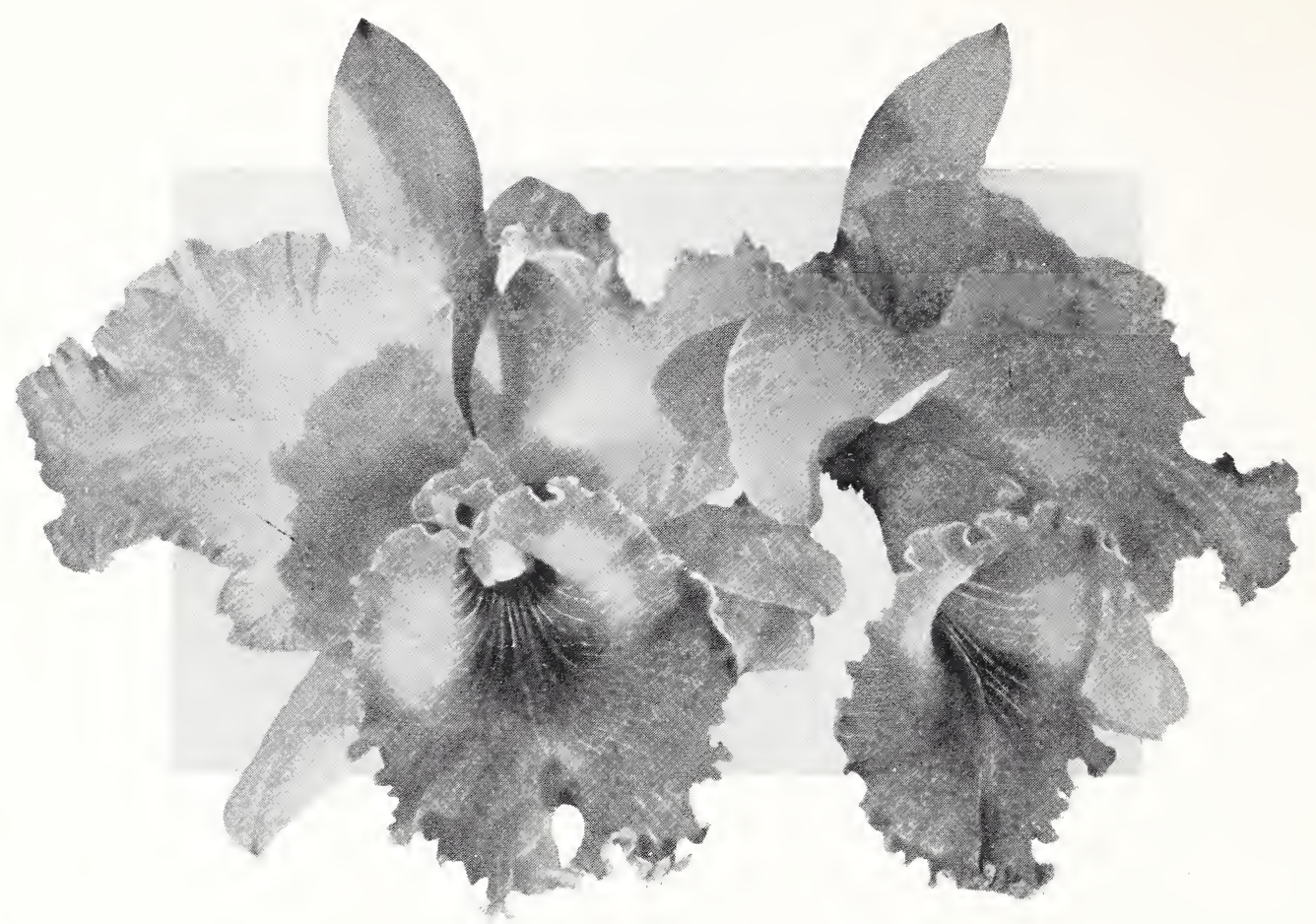

L. C. MRS. HAROLD LLOYD. (See page 24)

\section{Laeliocattleyas}

T His group of bigeneric hybrids gives a wonderful brilliance of color, the lip especially showing to good advantage. They are distinguished in the way the flowers are held above the foliage, and their free manner of growth. The hybridist's art has produced varieties that will give almost yearround succession of bloom, and most of them can be depended on to flower on every growth. These plants have four or five bulbs with one lead, and we shall be glad to quote you on larger specimens.

The illustration above shows an ideal type of this group. The shape is nearly perfect, the coloring is rich throughout, and the texture is such as to assure a long lasting flower.

L. C. Авbotsford (L. C. Domos X C. Mossia) . . . . . . $\begin{aligned} & \text { Each } \\ & \$ 20.00\end{aligned}$ Good Variety . . . . . . . . . . . . . . . . 30.00

L. C. A. C. Burrage (L. C. Herscentia $\times$ C. Dowiana). The variations range from white petals and sepals to deepest rose . . . 20.00 Special Variety . . . . . . . . . . . . . . . . . 30.00

L. C. Andromeda (C. Dowiana X L. flava) . . . . . . . 25.00

L. C. Antimachus (C. gigas X L. C. Dominiana). . . . . . . . 20.00

L. C. Aphrodite (C. Mendeli $\times$ L. purpurata). We have some very distinct forms of this fine hybrid . . . . . . . . . . . 15.00 Special Variety . . . . . . . . . . . . . . . . . . 30.00

L. C. Arran (L. C. Australia X C. Gaskelliana) . . . . . . . . . 15.00 


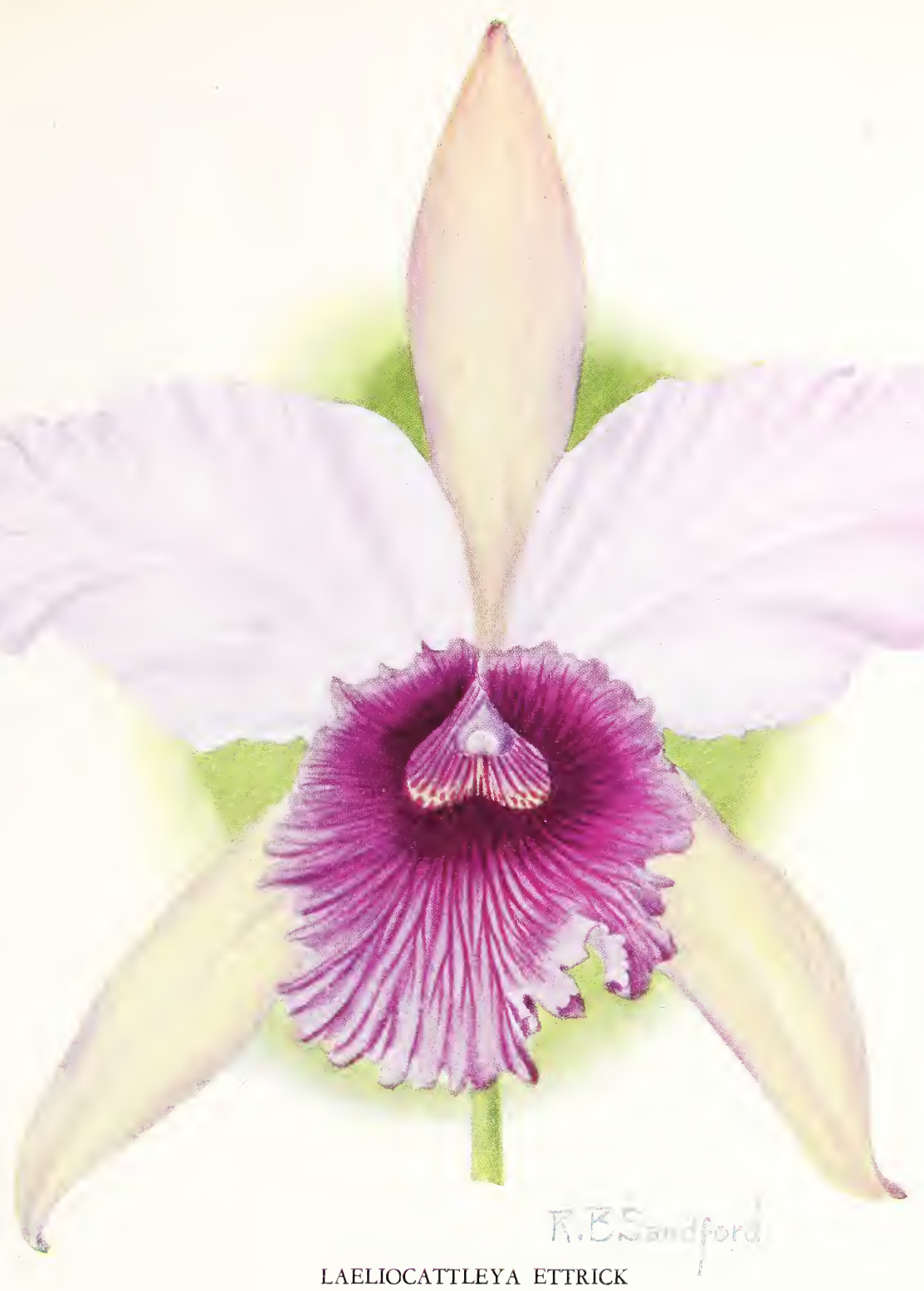

L. C. Arras (C. Mossice $\times$ L. C. Aphrodite). The addition of C. Mossiae makes a slightly fuller flower. . . . . . . . . . \$20.00

L. C. Arturo (L.C. Hyeana $\times$ C. gigas). A strong growing variety with deep color . . . . . . . . . 20.00

L. C. Atawood (C. Atalanta X L. C. Geo. Woodhams) . . . . . 18.00 Specimen Plant . . . . . . . . . . . . . . 30.00

L. C. Athene (L.C. callistoglossa $\times$ L.C. St. Gothard). Good sized flowers showing a tendency to favor either parent . . . . . . 25.00 Good Variety . . . . . . . . . . . . . . . 50.00 
L. C. Autodoin (C. Octave Doin X L. autumnalis). Long-stemmed spray in early Winter .

$\$ 15.00$

L. C. Barbarossa (C. Trianae $\times$ L. C. callistoglossa). Fall blooming, has very deep color in the lip Good Variety

L. C. Basil (C. Mantini X L. C. callistoglossa). A strong grower with dark flowers

L. C. Beatrice (C. Scbroederce $\times$ L. C. callistoglossa). C. Schroderce imparts a softness of color to all its progeny

18.00

L. C. Bella (C. labiata $\times$ L. purpurata). A favorite Winter variety . . 20.00

L. C. Beppo (L. C. Alex $\times$ C. Syros) . . . . . . . . . . . 20.00 Good Variety . . . . . . . . . . . . . . . 35.00

SPECIAL VARIETY . . . . . . . . . . . . . 50.00

L. C. Black Prince (C. Hardyana X L. C. bletchleyensis) . . . . . 18.00

L. C. Blanche (C. Helen Langley $\times$ L. flava) . . . . . . . . 18.00

L. C. Bletchleyensis (C. gigas $X$ L. tenebrosa). Many have a lovely bronze tint in petals and sepals... . . . . . . . 15.00 Fine Variety . . . . . . . . . . . . . . . 30.00

L. C. Britannia (C. gigas $\times$ L. C. Canhamiana). A useful flower of fine size . . . . . . . . . . . . . . . . . 20.00 Specimen Plant . . . . . . . . . . . . . 35.00

L. C. callistoglossa (C. gigas $\times$ L. purpurata). This primary hybrid has proved a splendid subject for the hybridist . . . . . 20.00 Specimen Plant . . . . . . . . . . . . . . . 35.00

L. C. Cameronian (L. C. Dominiana X C. Princess Royal). . . . . . . 15.00 Good Variety . . . . . . . . . . . . . . . . 30.00

L. C. Canhamiana (C. Mossice $\times$ L. purpurata). One of the best June flowering varieties we have . . . . . . . . . . . 20.00 Specimen Plant . . . . . . . . . . . . . . . 35.00

L. C. Caprice (L. C. G. S. Ball X C. intertexta) . . . . . . . . 15.00

L. C. Carmencita (C. Dowiana $\times$ L. C. luminosa). Petals and sepals range from clear yellow to deep bronze . . . . . . . . . 25.00 Special Variety . . . . . . . . . . . . . . . . . 50.00

L. C. Colmaniana (C. Dowiana X L. C. callistoglossa). . . . . . 25.00

L. C. Cortina (C. Empress Frederick $\times$ L. C. callistoglossa). Inherits much of its parents' deep coloring . . . . . . . . . . . 20.00

L. C. Creole (C. gigas X L. C. luminosa) . . . . . . . . . 25.00

L. C. Decia (C. Dowinana $\times$ L. Perrini). A very free blooming variety . 20.00

L. C. Delight (L. C. luminosa $\times$ L. C. Golden Oriole). A fine addition to the ranks of golden colored varieties . . . . . . . 25.00

L. C. Dominiana (C. Dowiana $\times$ L. purpurata). Although introduced in 1899, is still as popular as ever . . . . . . . . 20.00 


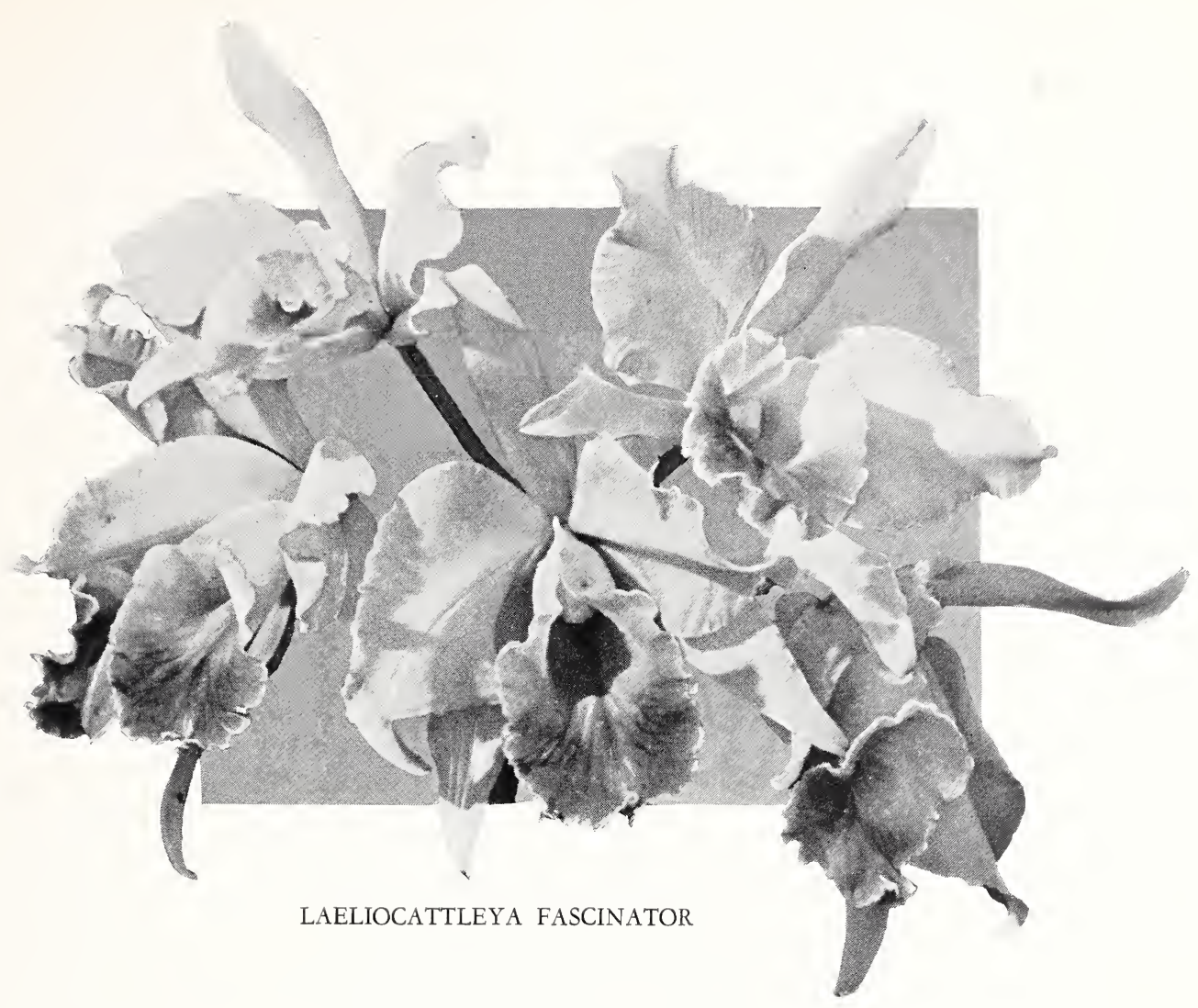

L. C. DR. R. Schiffman (C. Mendeli $\times$ L. C. callistoglossa)

.$\$ 18.00$

L. C. Duvaliana (C. Lueddemanniana $\times$ L. purpurata).

L. C. Eтtrick (C. Dowiana $\times$ L. C. bletchleyensis)

L. C. elegans (C. Leopoldi $\times$ L. purpurata) . Specimen Plants.

L. C. Eva Baldwin (L. C. Dominiana $\times$ C. Percivaliana).

L. C. eximia (C. Warneri $\times$ L. purpurata). Very free blooming. Where a number are grown, it is found that a few flowers can be cut at all times of the year

L. C. Fascinator (C. Schroederce $\times$ L. purpurata). We have over 800 plants of this variety alone. It has a very free blooming habit and holds the blooms well above the foliage. (See illustration above.) Light variety

L. C. F. G. SEAley (L. cinnabarina $\times$ C. Empress Frederick)

L. C. F. L. Wurzburg (C. Leda X L. C. E. B. Dane)

L. C. G. G. Whitelegge (C. Hardvana X L. C. callistoglossa) 
L. C. Gladiator (C. Mossia X L. C. callistoglossa). Makes a splendid plant for effective staging . . . . . . . . . . $\$ 18.00$ Good Variety . . . . . . . . . . . . . . 30.00

L. C. Grisette (L. C. eximia X L. C. Golden Oriole). Many have lovely bronze tints. Time of flowering is variable . . . . . . 15.00 Yellow Variety . . . . . . . . . . . . . . . 30.00

L. C. Hippolyta (C. Mossice $\times$ L. cinnabarina). The distinctive coloring is much appreciated . . . . . . . . . . . . 25.00

L. C. Hon. Mrs. Astor (C. Gaskelliana X L. xantbina) . . . . . 18.00

L. C. Hyeana (C. Lawrenceana $\times$ L. purpurata) . . . . . . . . 18.00

L. C. Isfield (C. gigas $\times$ L. Pacavia) . . . . . . . . . . . 18.00

L. C. Ivanhoe (C. Dowiana $\times$ L. C. eximia). A good type of flower with lasting qualities . . . . . . . . . . . 20.00

L. C. JacQuinetta (C. Empress Frederick $\times$ L. C. Lustre) . . . . . 30.00 Good Variety . . . . . . . . . . . . . . 50.00

L. C. Jas. Goodier (L. C. Canhamiana X C. Empress Frederick). This newer origination is a happy combination of size and shape; many have exceptional coloring . . . . . . . . . . . . 20.00 Good Dark Variety . . . . . . . . . . . . . 35.00

L. C. Josephine (C. Triance $\times$ L. crispa) . . . . . . . . . . 20.00

L. C. Kathleen Grey (L. C. Canhamiana X L. tenebrosa) . . . . . 18.00

L. C. Lamorna (C. Hardyana $\times$ L. C. Dominiana). Inclines more to the latter mentioned parent . . . . . . . . . . 18.00

L. C. Lillian M. Stevens (L. C. Carmencita X C. Percivaliana) . . . 20.00

L. C. luminosa (C. Dowiana $\times$ L. tenebrosa) . . . . . . . . . 25.00 AUREA. Fine variety . . . . . . . . . . . . 50.00

L. C. Margaret Kirkwood (L. C. Alex X C. Maggie Raphael) . . . 25.00

L. C. Mary Crowe (L. C. C. G. Roebling X C. Lueddemanniana) . . . 18.00

L. C. Martineti (C. Mossice $\times$ L. tenebrosa). The modified tenebrosa color shows to good advantage . . . . . . . . . . 20.00 Good Bronze Variety . . . . . . . . . . . . . 35.00

L. C. Massasoit (L.C. Nella $\times$ C. Hardyana Ruby). The whole flower is of lovely, deep color . . . . . . . . . . . . . 15.00 Extra Dark Variety . . . . . . . . . . . . . 30.00

L. C. Memoria H. A. Tracy (C. Hardyana $\times$ L. C. Canhamiana). A very good commercial variety . . . . . . . . . . . . 20.00 ALBA . . . . . . . . . . . . . . 30.00

L. C. Milo (C. Mossiae $\times$ L. C. Hyeana). Some forms of this fine variety are very distinct . . . . . . . . . . . . . . 18.00 Extra Dark Variety . . . . . . . . . . . . . 25.00

L. C. Miss Dorothy Bushnell (C. Dowiana X L. C. Bryan) . . . . 20.00 


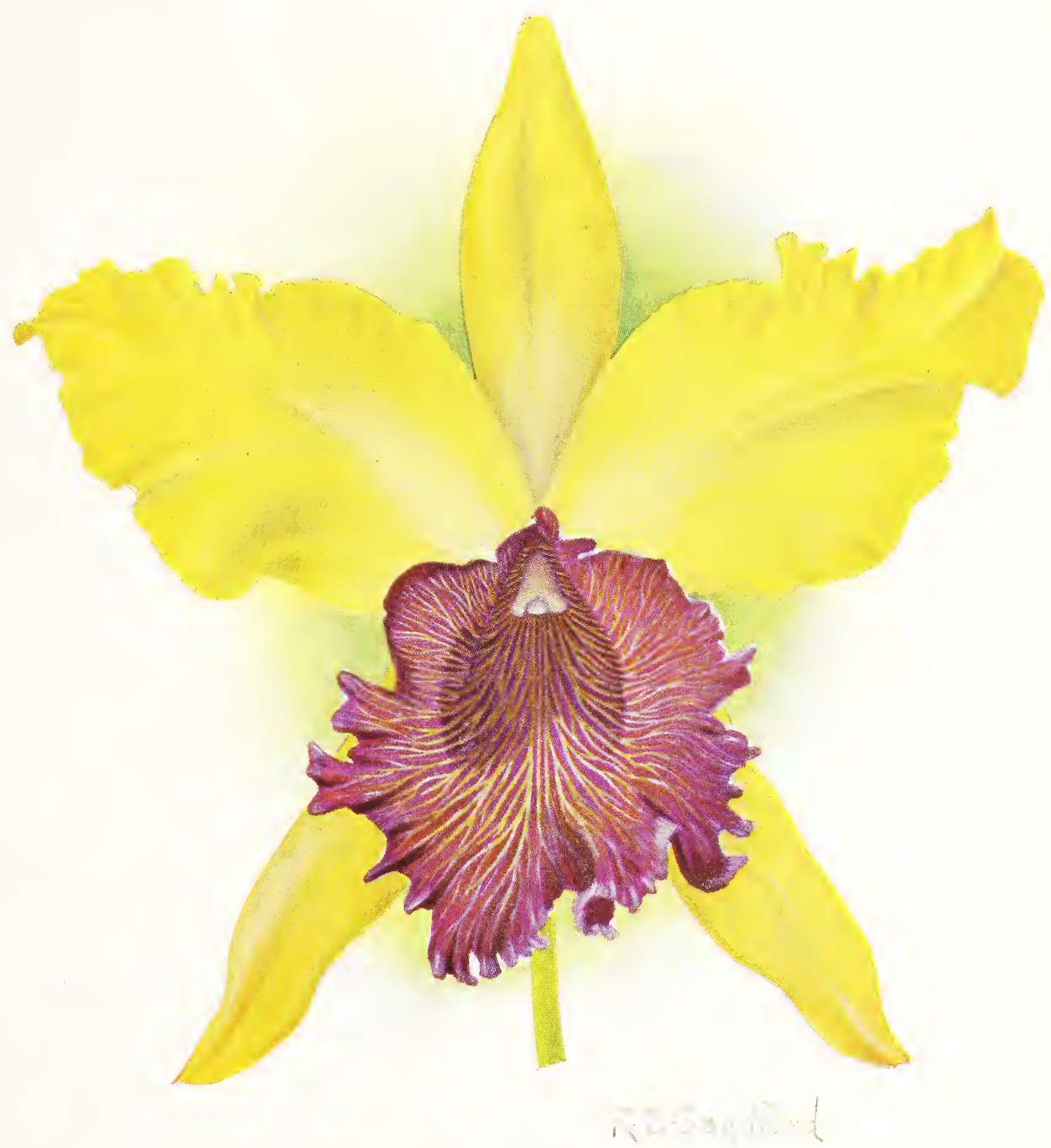

LAELIOCATTLEYA REDSKIN. (Sec page 2f) 
L. C. Mossemiliana (C. labiata $\times$ L. C. bletchleyensis).

L. C. Mrs. Harold Lloyd (L.C. Aphrodite X C. Van Houtte). Introduced in 1928, this has proved of wonderful merit

Larger Plants

Good Variety

ORCHIDWOOD VARIETY. (See illustration, page 18.) . . 100.00

L. C. Mrs. M. A. House (L. C. Golden Oriole X C. Hardyana) . . . 20.00 Good Variety. Yellow petals and sepals, with a beautiful deep lip

L. C. Mrs. Reginald Brade (C. Schroederce $\times$ L. C. Apbrodite)

L. C. Mrra (C. Triance $\times$ L. flava) Special Variety

L. C. Nella (C. labiata $\times$ L. C. Dominiana). A good Fall flowering variety

L. C. Nomad (L. C. brugensis $\times$ C. Dupreana)

L. C. Nysa (C. gigas $\times$ L. crispa) .

L. C. Osprey (C. Dowiana $\times$ L. C. Apbrodite)

L. C. Page Platt (L. C. Appam X C. Hardyana)

L. C. Pallas (C. Dowiana $\times$ L. crispa) Specimen Plant

L. C. Pathan (C. Dowiana $\times$ L. C. Dominiana)

L. C. Phoenix (C. Dowiana $\times$ L. C. Henry Greenwood). Very well balanced flower, having fine color .

L. C. Portita (L. C. callistoglossa $\times$ C. Portia). Slightly larger than C. Portia, and of similar growth

20.00

L. C. Queenie (L. C. C. G. Roebling X L.C. Dominiana) . . . . . 18.00

L. C. Rabeiana (C. Dupreana X L. C. purpurata) . . . . . . . 20.00

L. C. Ramscapelle (C. Dowiana $\times$ L. C. Hyeana). The extra dark lip is a strong feature . . . . . . . . . . . . . 20.00

L. C. Redskin (L. C. luminosa $\times$ C. Empress Frederick). The tawny tones predominating suggest the original American . . . . . 25.00 Good Variety . . . . . . . . . . . . . . . . 50.00 SPECIAL YELLOW VARIETY. (See Color Plate, page 23) 100.00

L. C. Robina (C. Dowiana X L. C. Robin Measures) . . . . . . 18.00

L. C. Roger Sander (C. Mossice $\times$ L. C. luminosa). Many are of bronze tint. . . . . . . . . . . 30.00

L. C. Rosarita (L. C. Hyeana $\times$ C. Hardyana). A dark variety; flowers at a time when such are scarce . . . . . . . . 20.00

L. C. Rosalind (C. Triance X L. C. Dominiana) . . . . . . . . 20.00

L. C. S. A. Salvage (C. Gaskelliana X L. C. Dominiana) . . . . . 30.00 
L. C. Scarsdale (L. C. Elsa $\times$ C. Triana $)$

L. C. Schroedere (C. Maggie Raphael var. alba X L. C. bella var. alba) $\quad 50.00$

L. C. Secaucus (L. C. Rutherford X C. Dowiana) . . . . . . . 20.00

L. C. S. O. Stevenson (C. Empress Frederick $\times$ L. purpurata). Fine bold flower of good shape . . . . . . . . . . . . . 18.00 Specimen Plants . . . . . . . 35.00

L. C. Soulange (C. Dowiana $\times$ L. C. Lustre). $\quad 35.00$ Good Variety . . . . . . . . . 50.00

L. C. St. George (C. Fabia X L. C. St. Gothard) . 30.00

L. C. Thyone (C. Dowiana $\times$ L. C. Ophir) . 35.00

L. C. Tuckahoe (L. C. Linda X C. Mossia) : . . . 20.00

L. C. Whitiniae (C. Harrisonianna $\times$ L. purpurata) . $\quad 15.00$

L. C. Weehawken (L. C. Ernest B. Dane $\times$ C. Dowiana). This American origination has not been widely distributed yet. Our stock contains many fine forms . . . . . . . . . . . . 30.00

L. C. Wellesleyi (C. gigas $\times$ L. C. Martineti). Out of this batch has come a Gold Medal winner. We have flowered many wonderful forms . . . . . . . . . . . . 2500 Good Variety . . . . . . . . . . . . . . . . 50.00

var. Edward H. Roehrs. (See Color Plate, page 2.) . . . 100.00 var. OrCHIDWOOD . . . . . . . . . . . . . . . . . . . . . . . . .

\section{\%)}

\section{Sophrolaeliocattleyas}

TN THESE trigeneric hybrids an added shade of color derived from the little red Sophronitis Grandiflora has been introduced by the Orchid hybridist. Although slightly smaller than the average Cattleya hybrid, this lack of great size is more than compensated by the brilliancy of color.

S. L. C. Baldwini (C. gigas X S. L. C. Meuse) . . . . . . . . \$25.00

S. L. C. Mrs. George Baldwin (L. purpurata X S. L. C. Meuse) . . 20.00 Good Variety . . . . . . . . . . . . 35.00

\section{๑)}




\section{Cattleya Species}

(1) RIGINALLY obtained from their native habitat, the woods of certain Central and South American countries, these species formed the limits of many commercial establishments in this country. With the introduction of Quarantine No. 37, there has been no great addition to the stock grown here, except through propagation by division, and many of these fine species are exceedingly scarce. Our stock is very representative and embraces many worthy specimens of this genus. Healthy plants of four and five bulbs, with one lead, are quoted here.

C. Bowringiana. Has lovely spikes of over a dozen flowers in Fall. . \$10.00

C. Dowiana aurea . . . . . . . . . . . . . . . 30.00

C. Gaskelliana. A favorite where flowers are desired in Summer . 15.00

C. Gigas. Largest of the Cattleya species . . . . . . . . . 15.00

Special V ariety . . . . . . . . . . . . . . . . . . . . . . 25.00

Frau Melanie Beyrodt. White petals and sepals, deep purple

lip. Has made many fine white petalled hybrids . . . . . 35.00

C. Harrisoniana (Summer). Lilac rose color . . . . . . . . 12.00

C. intermedia (Summer). Pale rose color . . . . . . . . . 12.00

C. LABiAta. As a parent, has produced many fine Fall flowering hybrids . 10.00

Good Variety ............... 25.00

C. Lueddemanniana. Large, bold flowers often twice a year. $\$ 15.00$ to 25.00

C. Mendeli. Large, well-shaped flowers in Spring . . . . . . 18.00

C. Mossie. In various shades, from white to deep rose . . . . . 15.00

Good Variety . . . . . . . . . . . . . . . . . . 25.00

FINE VARIETY . . . . . . . . . . . . . . 50.00

var. Mrs. J. T. Butterworth. Known as the World's finest

Mossiz . . . . . . . . . . Price on application

C. Percivaliana. Rather smaller than the average Cattleya, but bloom-

ing at Thanksgiving, is much appreciated . . . . . . 15.00

Good Variety . . . . . . . . . . . . . . . 25.00

C. Schroederæ. Delicate pale color with lovely fragrance . . . . 15.00

C. Skinneri (Spring). Rose purple . . . . . . . . . . . 12.00

C. Triank. Our stock of this fine Winter flowering species is very com-

plete . . . . . . . . . . . . . . . . 10.00

Good Variety . . . . . . . . . . . . . . . . 20.00

Distinct Variety . . . . . . . . . . . . . . . . 25.00

BackhouseanA . . . . . . . . . . . . . . 30.00

ALBA . . . . . . . . . . . . . . . . . 30.00

Fine Variety . . . . . . . . . . . . . . . 100.00

A. C. Burrage . . . . . . . . . . . . . . . . . . . 100.00

Mrs. A. Cooley . . . . . . . . 50.00

Mrs. C. Moore . . . . . . . . . . . . . 50.00

The Premier . . . . . . . . . . . . . . . 75.00 


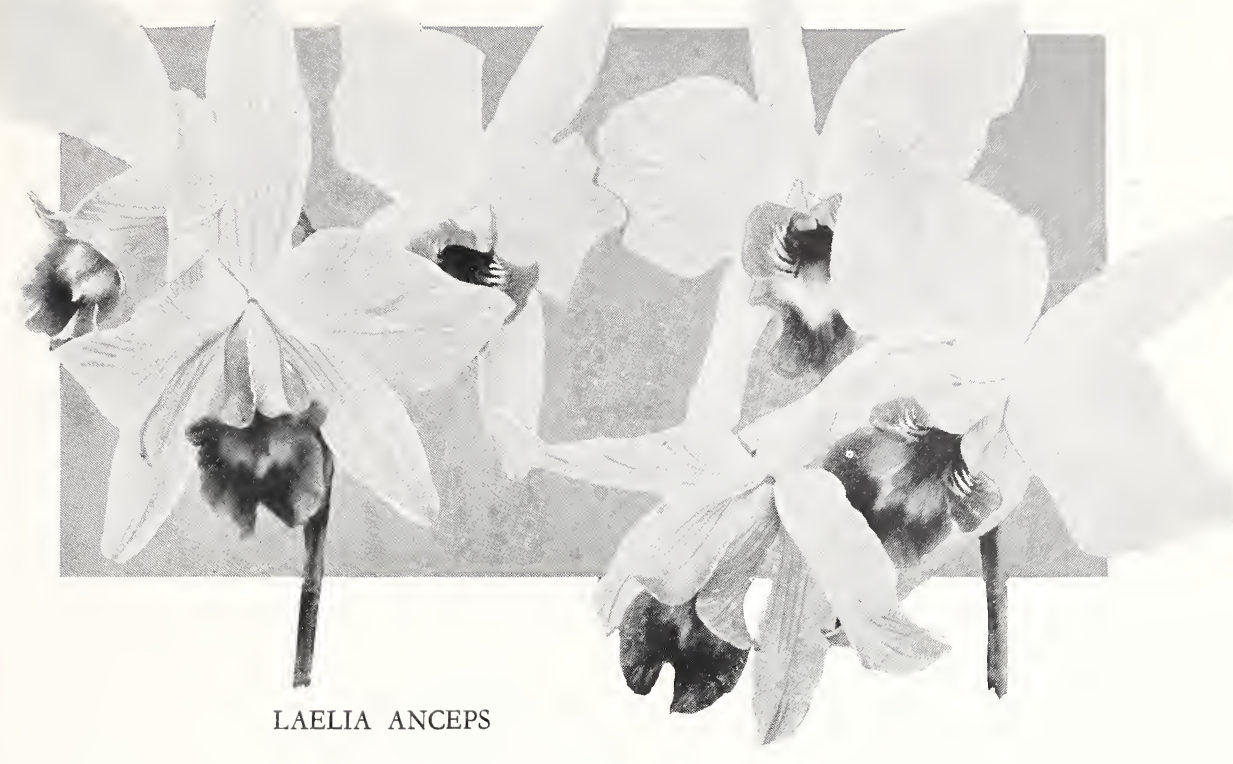

\section{Laelia Species}

Olosely related to the Cattleya family, requiring similar cultural treatment, and of very free flowering habit. They have eight, instead of the usual four, pollen masses, which constitutes the main division between Cattleya and Laelia.

L. Anceps. We have some very good forms of Alba, Sanderiana, Schroederix, etc., all of which flower in Winter (See illustration above.) $\$ 10.00$

Good Variety . . . . . . . . . . . . . . . 15.00

L. CRISPA (Brazil). Summer . . . . . . . . . . . 10.00

L. Gouldiana. The Christmas flower of bright rose purple . . . . 12.00

L. purpurata. Whose influence has been felt through almost the entire

range of Laeliocattleyas. A strong growing plant of easy culture. 12.00

Specimen Plants . . . . . . . . . . . . . . . 25.00

L. tenebrosa. Bronze petals and sepals . . . . . . 12.00 


\section{Cymbidiums}

UR stock of Cymbidium species and hybrids is very comprehensive, those listed representing only a part of the numerous varieties on hand. We are constantly adding to this assortment any of the new or fine varieties available here or abroad. Quotations on any size plant will be freely submitted upon request, prices ranging from $\$ 15.00$ for plants of two or three bulbs up to $\$ 100.00$ for specimens and fine varieties.

\begin{tabular}{|c|c|c|}
\hline Species & Native of & \\
\hline Aliofolium & Burma & $\$ 15.00$ \\
\hline INSIGNE & Annam. & $\$ 20.00$ to 30.00 \\
\hline LOWIANUM & Burma. (See illustration, page 29.) & 15.00 to 35.00 \\
\hline Tracyanum & Burma. & 15.00 to 25.00 \\
\hline
\end{tabular}

\section{HYBRIDS}

Alexanderi (eburneo-Lowianum $X$ insigne Sanderi).

Butterfly (insigne Sanderi $\times$ Lowianum-grandiflorum)

Capella (Pauwelsi $\times$ Wiganianum)

Castor (insigne Sanderi $\times$ Woodhamsianuin)

ERICA (grandiflora $\times$ Pauwelsi)

Egret (Gottianum $\times$ Pauwelsi)

ERIN (grandiflorum $\times$ gattonense)

Gottianum (eburneum $\times$ insigne)

HANBURYANUM (erytbrostylum $\times$ Tracyanum)

Lowio-Schroeder $Æ$ (Lowianum $\times$ Schroederce)

Moira (Pauwelsi $\times$ Tracyanum)

Pauwelsi (insigne Sanderi $\times$ Lowianum)

Schlegeli (insigne Sande $i \times$ Wiganianum)

Sybil (eburneum $\times$ Pauvelsi)

\section{Cypripedium}

$\mathbb{T}$ HESE are popular known as the "Lady Slipper" Orchid, and are amongst the easiest Orchids to grow. They propagate easily by division, and last a very long time in flower.

Cypripedium Harrisianum .

Larger Plants

Cypripedium Lawrenceanum

Larger Plants

10.00

Cypripedium Maudie

$$
\text { La'ger Plants }
$$

15.00

Selenepedium Grande

Selenepedium Schroeder . 


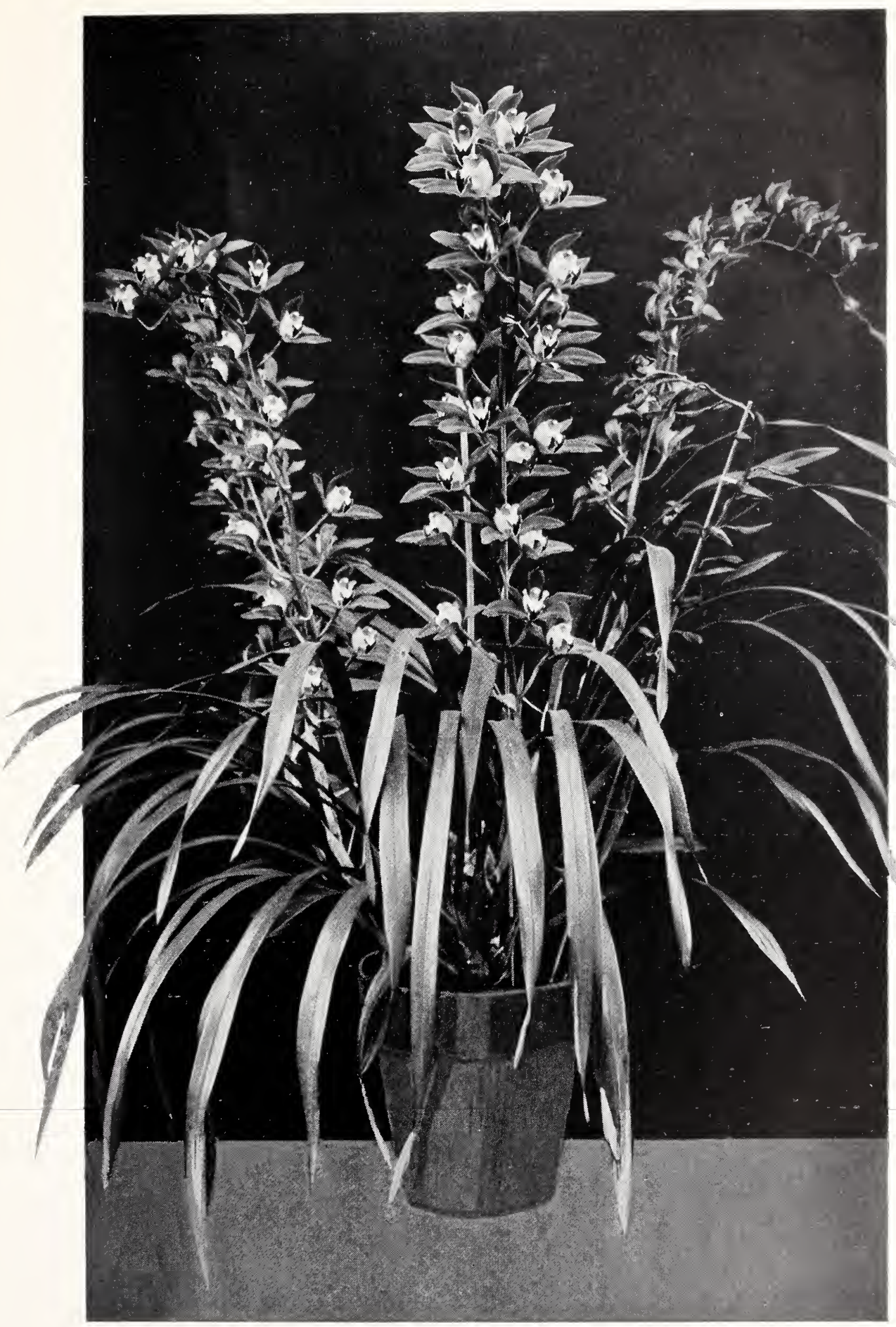

CYMBIDIUM LOWIANUM. (See page 28)

New Rochelle, N.Y. 


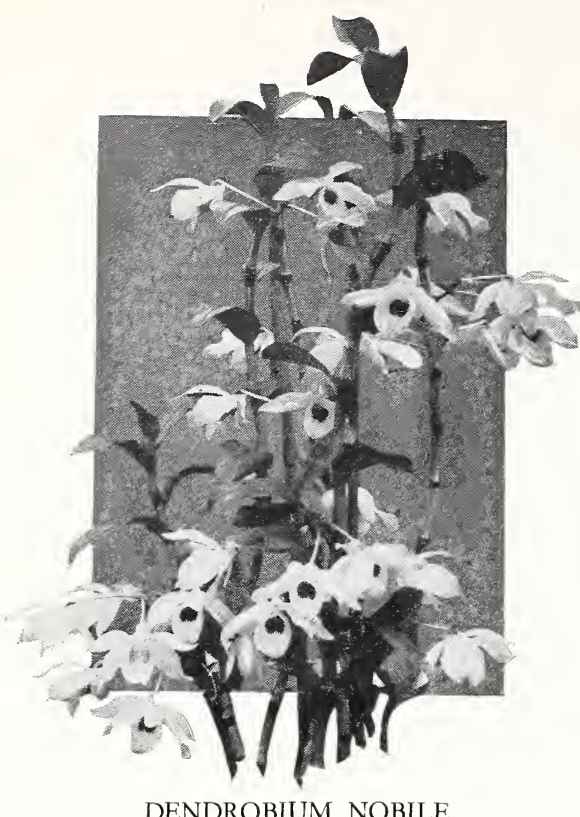

DENDROBIUM NOBILE

\section{Miscellaneous Species}

V ERY interesting Collections of these species can be built up for a small sum. The flowers are not so showy as the Cattleyas, but their lasting qualities make them invaluable for display in the conservatory.

Angracum eburneum (Spring) . $\quad$ \$25.00

Brassavola Digbyana. A tough, leathery-looking species from the forests of Honduras, revels in plenty of heat, with a little shade. (Summer)

Brassia Brachiata . . \$5.00 to 10.00

Brassia Verrucosa. Greenish flowers, spotted with purple. (Spring) $\quad 5.00$

Bulbophyllum Careyanum (Summer) . . . . . . . . . . 10.00

Coelogyne cristata. Lovely sprays of white flowers in early Spring . 10.00 Large Plants . . . . . . . . . . . . . . 15.00

Coelogyne Dayana. Long chains of yellow and brown flowers. Spring. 7.50

Dendrobium Brymerianum-6 bulbs, 1 lead . . . . . . . . 15.00

Dendrobium Chrysotoxum. Sprays of golden yellow blooms. (Spring) . 8.00

Dendrobium fimbriatum (Spring) . . . . . . . . . . . . 10.00

Dendrobium Moschatum (Late Spring) . . . . . . . . . 7.50

Dendrobium nobile. A most useful Orchid, having many clusters of showy flowers in early Spring . . . . . . . . 8.00

Dendrobium phalaenopsis. With terminal spikes of rose colored flowers.

(Fall) . . . . . . . . . . . . . . . 10.00

Dendrobium thyrsiflorum. Long drooping sprays of gold and white.

(Spring). . . . . . . . . . . . . . 8.00

Epidendrum ciliare (Summer) . . . . . . . . . . . . . 5.00

Epidendrum cochleatum (Summer) . . . . . . . . . . . . 10.00

EPIDENDRUm PRismatocarpum. Long, lasting flowers of yellow, blotched with purple. The Rainbow Orchid (Summer) . . . . . 10.00

Epidendrum vitellinum. A deep red spray (Fall) . . . . . . . 10.00

Miltonia vexillaria (Spring) . . . . . . . . . . . . . . . . 8.00

Miltonia St. Andre (Spring) . . . . . . . . . . . . . . 10.00

Odontoglossum bictoniense. Has spikes often 18 inches long, of a lovely combination of rose and yellow green (Winter) . . . . . 10.00 
Odontoglossum citrosmum. Pendulous sprays of 15-20 flowers (Spring). \$10.00

Odontoglossum pulchellum. The "Lily of the Valley" Orchid. Fragrant flowers of pure white (Winter) . . . . . . 7.50

Oncidium Altissimum. Long sprays, 3-4 feet, of yellow, blotched with brown (Spring)

Oncidium flexuosum. Dainty little yellow flowers. (Late Summer) . 8.00

Oncidium LuRidum. Long sprays, 4-5 feet, of brownish-purple flowers. (Spring).

Oncidium ornithorhynchum. Resembles a flight of birds in the flower formation (Winter) . . . . . . . . . . . 10.00

Oncidium splendidum. One of the most useful of spray Orchids (Winter) 8.00

Oncidium tigrinum (Winter) . . . . . . . . . . . . 10.00

ONCIDIUM VAricosum Rogersi. Large sprays of fair-sized, yellow flowers. (Winter) . . . . . . . . . . . . . 8.00

Oncidium Wentworthianum (Summer) . . . . . . . . . . 5.00

Platyclinius Glumacea (Spring) . . . . . . . . . . . . 8.00

Sobralia macrantha. The reed-like stems and leaves are quite decorative; flowers resemble Cattleyas (Summer) . . . . . 5.00

VANDA TERES. With its hybrid, Miss Joachim, whose large, rose-colored flowers find a ready market (Spring and Fall). . . . . 8.00

Zygopetalum Discolor (Spring) . . . . . . . . . . . 5.00

Zygopetalum Mackayi (Late Fall) . . . . . . . . \$10.00 to 20.00

\section{Sundries}

Fresh Osmunda Fiber . . . . . . . . . . . per sack, $\$ 3.50$

Fresh Osmunda Fiber-Picked, ready for potting . . . per sack, 5.00

Live Sphagnum Moss . . . . . . . . . . . . . per sack, 3.50

Wire Hangers, 18 inches long . . . . . . per dozen, single, 2.00

Wire Hangers, 18 inches long . . . . . perdozen, double, 2.50

Celluloid Labels, 4 inches long . . . . . . . . . per 100, 4.00 


\section{Hybrid Seedlings}

$\pi$

OuR endeavor to assure the Orchid-growing public of the highest quality seedlings, we have purchased the finest parent plants known whenever available. Many of our stud plants have cost from $\$ 250$ to $\$ 750$, while $\$ 10,000$ was paid for the stock of Cattleya Mossix Mrs. J. T. Butterworth, which is recognized by Orchid experts the world over as absolutely the finest Cattleya Moosix ever seen. A five-bulb division of Sophrolaeliocattleya Radians which we have used to make several of our crosses is valued at $\$ 1,000$, while a number of seedlings acquired through the purchase of the Roehrs Collection were developed from parent plants of equal value. We have what is probably America's most expensive commercial collection of Orchids being used to develop new hybrids which are to be offered to the public. They include Cattleyas, Laeliocattleyas, Brassocattleyas, Brassolaeliocattleyas, Sophrocattleyas, Sophrolaeliocattleyas, Rolfearas, Potinaras and a number of spray varieties which we can offer at the following prices:

\section{Each}

Сомmunity Pots-10 to 20 seedlings .

$\$ 1.00$ to $\$ 5.00$

1 YeAR OLD -Average $11 / 2$ inch pots .

2 Years Old-Average 2 inch pots .

3 Years Old - Average 3 inch pots .

4 Years Old-Average 4 inch pots.

5 Years Old-Average 5 inch pots.

5 to 6 Years Old with Sheaths 10.00

Special Quotations on Seedlings in Quantity 


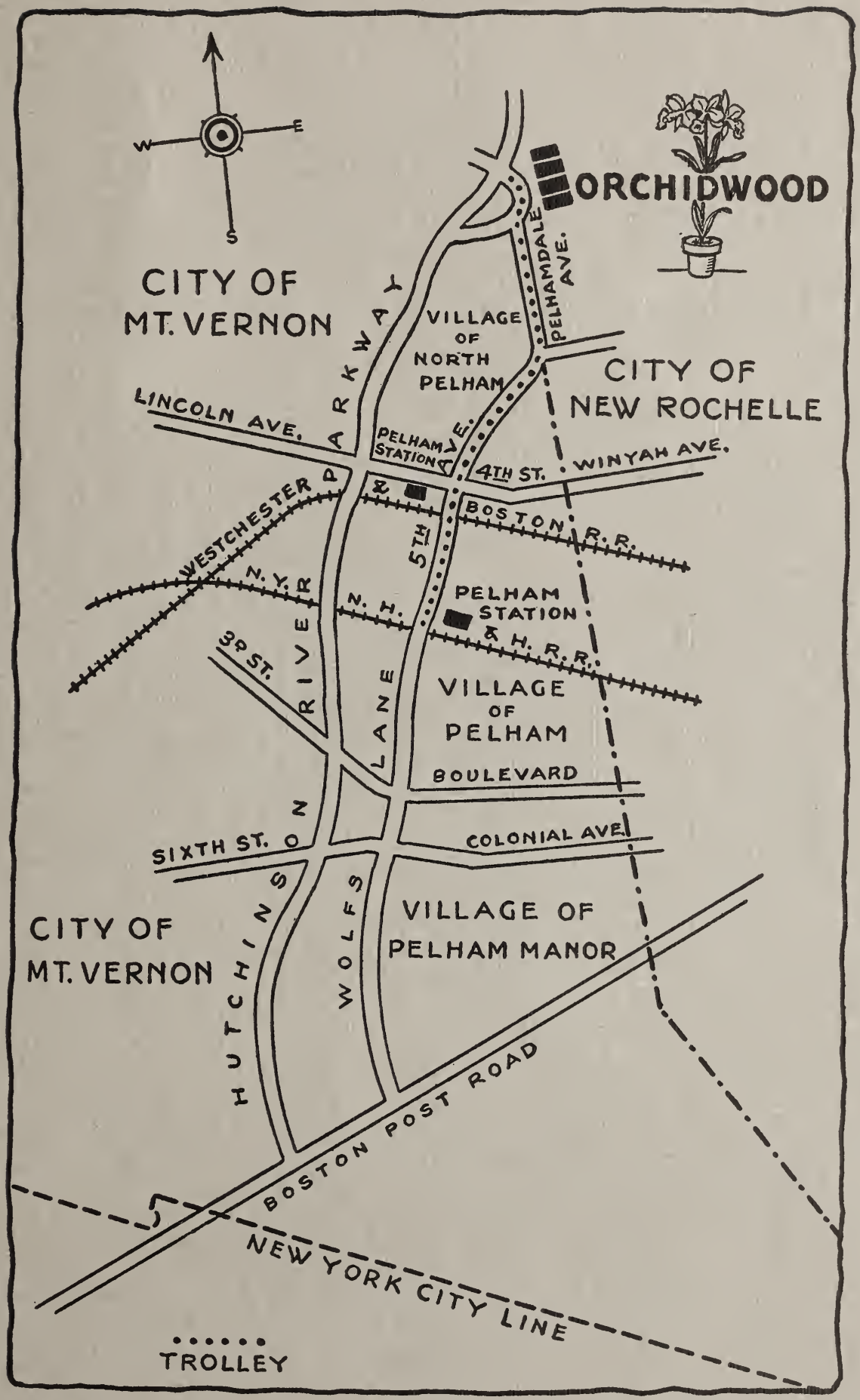


